OECDpublishing

THE ROLE OF

INNOVATION AND

HUMAN CAPITAL FOR

THE PRODUCTIVITY OF

INDUSTRIES

OECD SCIENCE, TECHNOLOGY AND INDUSTRY POLICY PAPERS

March 2021 No. 103 
This paper was approved and declassified by written procedure by the Committee for Industry, Innovation and Entrepreneurship (CIIE) on 15 January 2021 and prepared for publication by the OECD Secretariat.

\section{Note to Delegations:}

This document is also available on O.N.E. under the reference code:

$$
\text { DSTI/CIIE/WPIA(2020)7/FINAL }
$$

This document, as well as any data and any map included herein, are without prejudice to the status of or sovereignty over any territory, to the delimitation of international frontiers and boundaries and to the name of any territory, city or area.

COOECD (2021)

The use of this work, whether digital or print, is governed by the Terms and Conditions to be found at http://www.oecd.org/termsandconditions. 


\title{
The Role of Innovation and Human Capital for the Productivity of Industries
}

\author{
Emile Cammeraat, Lea Samek and Mariagrazia Squicciarini \\ (OECD Directorate for Science, Technology and Innovation)
}

This paper sheds light on the relationship between innovation, human capital endowment and upgrading, organisational capital (OC) and labour productivity. In addition to assessing correlations, it uses a Heckman selection model to address causal links and to account for the ways in which skills and investment in $R \& D$ affect the probability of innovating.

The analysis finds that innovative output, the proportion of OC-related workers, investment in training (especially in informal training) and physical capital intensity are positively and significantly related to productivity. In most estimates ICT skills, cognitive skills and the presence of highly skilled workers in an industry also emerge as having a significant and positive relationship with productivity. ICT skills further appear to indirectly shape productivity, through a positive relationship with innovation.

Keywords: Human Capital; ICT; Innovation; Labour Productivity; Organisational Capital; Patent; R\&D; Skills; STEM; Training

Acknowledgements: We are grateful to the delegates to the OECD Working Party on Industry Analysis (WPIA) and delegates to the OECD Committee on Industry, Innovation and Entrepreneurship (CIIE) for helpful comments and feedback. We thank Hélène Dernis for constructing patent counts at the country-industry level by matching data from the European Patent Office (EPO) Worldwide Patent Statistical Database (PATSTAT) with ORBIS@ data. 


\section{Table of contents}

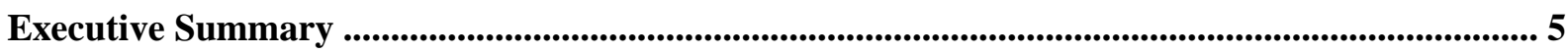

Chapter 1. Introduction ................................................................................................................................... 7

Chapter 2. Literature Review.................................................................................................................................. 9

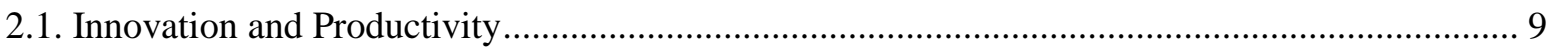

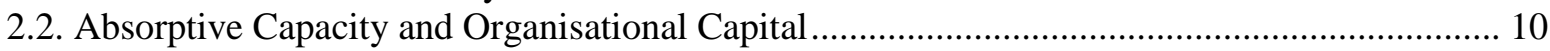

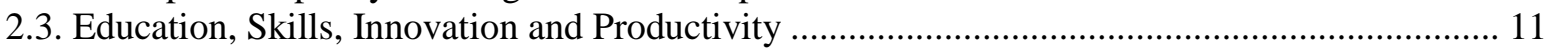

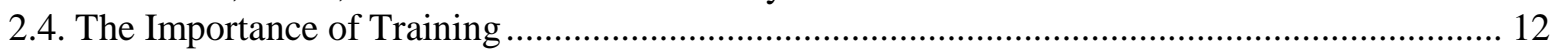

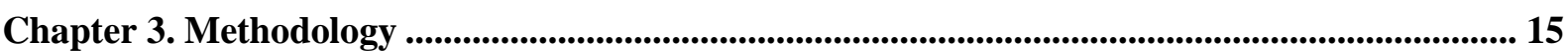

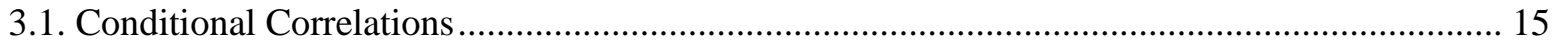

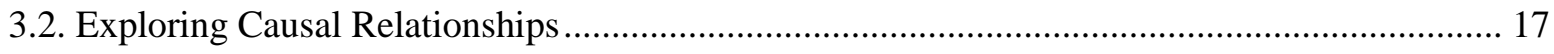

Chapter 4. The Relationship between Skills, Training, Innovative Output and Productivity ..... 19

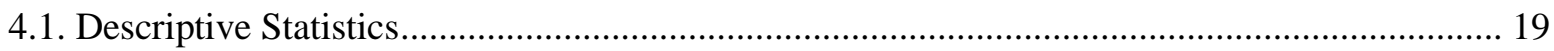

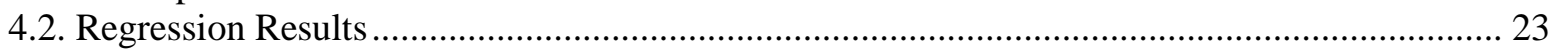

4.3. Sensitivity Analysis - What is the Role of STEM Skills for Productivity?.............................. 27

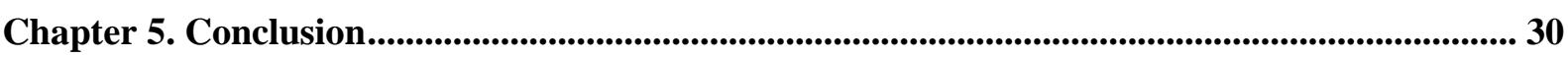

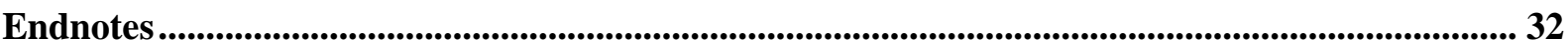

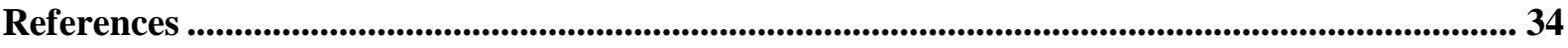

Annex A. Additional Tables and Figures .......................................................................................... 42

\section{Tables}

$\begin{array}{lr}\text { Table 3.1. Country and industry clusters } & 17\end{array}$

Table 4.1. Descriptive statistics of variables from the regression models 20

Table 4.2. Estimation results using OLS $\quad 25$

Table 4.3. Estimation results addressing self-selection $\quad 26$

Table 4.4. Estimation results with different fixed effects $\quad 29$

$\begin{array}{lr}\text { Table A.1. Correlation matrix } & 44\end{array}$

Table A.2. Full results: estimation results using OLS $\quad 45$

Table A.3. Full results: estimation results addressing self-selection 46

Table A.4. Full results: estimation results with different fixed effects $\quad 48$

\section{Figures}

$\begin{array}{ll}\text { Figure 4.1. Scatter plot: relationship between patents and labour productivity } & 21\end{array}$

$\begin{array}{lr}\text { Figure 4.2. Scatter plot: investment in total training and labour productivity } & 22\end{array}$

Figure 4.3. Scatter plot: investment in informal training and labour productivity 22

$\begin{array}{lr}\text { Figure 4.4. Industry clusters' coefficients } & 27\end{array}$

$\begin{array}{lr}\text { Figure A.1. Dendogram } & 42\end{array}$

$\begin{array}{lr}\text { Figure A.2. Histogram } & 42\end{array}$

Figure A.3. Scatter plots: investment in training 43 


\section{Executive Summary}

This paper investigates how innovation and human capital endowment and upgrading (as proxied by skill endowment and investment in different types of training) relate to labour productivity. In particular, it looks at how labour productivity and the probability of an industry to innovate are shaped by its workforce's cognitive skills (proxied by numeracy), task-based ICT and STEM skills, the dispersion of cognitive skills, and investment in different types of training (formal, non-formal and informal).

The work is motivated by the need to understand how different types of skills contribute to industries' innovation abilities and economic performance and, as training helps upskilling human capital, how innovation output and training relate to labour productivity.

To study these relationships, we rely on a number of purposely created indicators. First, patent counts at the country-industry level, compiled by matching patent applicants' names from the Worldwide Patent Statistical Database (PATSTAT), to firms, and then using industry classifications from company-level data contained in ORBIS $\odot$.

Second, we build on OECD estimates of investment in training, on indicators of cognitive and task-based skills as well as Organisational Capital (OC) workers constructed using data from the Programme of the International Assessment of Adult Competencies (PIAAC). We also use output information from the STAN dataset.

The analysis first proposes results based on conditional correlations and then on a Heckman two-step model, aimed to address potential selection and endogeneity biases. In the selection model, Research and Development (R\&D) expenditure is used as an exclusion restriction to estimate selection into innovative industries. The aim is to control for possible selection and self-selection of individuals with higher skills into more innovative firms.

The main findings of the analysis and their implications for policymaking are:

- Productivity increases significantly with innovative output, investment in training, the proportion of $O C$ workers and physical capital intensity. These findings are consistent both when potential selection issues are addressed and when they are not. A one percent increase in patents relates to 0.04-0.06 percent higher productivity and a one percent increase in investments in total training increases productivity by $0.19-0.21$ percent. Labour productivity further increases by 0.375 percent for a one percent increase in net fixed assets.

- When the effects of investment in formal, informal as well as non-formal training are explored individually, the biggest productivity gain is observed for informal training. A one percent increase in investment in informal training is associated with $0.26-0.27$ percent increase in productivity. This reduces to $0.17-0.18$ percent for non-formal training and to 0.07-0.09 percent for formal training, but remains highly significant throughout the different specifications proposed. This suggests that returns to learning-by-doing and learning from peers and supervisors are substantial and deserve further attention.

- ICT skills are positively related to productivity in most labour productivity models. Also ICT skills appear linked indirectly to labour productivity through their strong and positive correlation with innovative activities. A one standard deviation increase in the mean ICT skill score is associated with a 0.1 percent increase in labour productivity. 
- STEM skills are only important for productivity when differences between individual countries are controlled for. A one-point increase in the average STEM score relates to a 0.2 percent increase in productivity. This finding is not robust when no fixed effects (FE) or when cluster FE are used.

- Median cognitive skills are not associated with productivity, but their dispersion is positively related to productivity in the majority of models. This suggests that within the top 50 percent of the cognitive skill distribution, the top 10 percent is more important than the median, confirming that highly skilled human capital is also important for the productivity of firms. This may contribute to explain a number of stylised facts proposed in existing literature such as skill premia as well as selection, self-selection and matching on the labour market.

The results call for the need to upgrade ICT task-based skills to facilitate innovative activities and improve productivity. Moreover, they highlight the importance of informal training, suggesting that it is crucial for policy makers to engage with and encourage firms to evolve into learning organisations, as these are the most productive ones. 


\section{Chapter 1. Introduction}

Existing research has shown the importance of investment in Research and Development (R\&D) for innovation output and of innovation for economic performance (Crépon, Duguet and Mairesse, 1998 ${ }_{[1]}$; Criscuolo, 2009 $9_{[2]}$; Mason, Rincon-Aznar and Venturini, 2019 ${ }_{[3]}$ ). However, while human capital is held to be of utmost importance for both innovative activities and economic performance (Romer, 1990 [4]; Mankiw, Romer and Weil, 1992 $2_{[5]}$; Diebolt and Hippe, 2018[6] ), relatively little is known about the very characteristics of human capital, i.e. the type of skills, that are key to translate R\&D into innovative output, and for innovative output to boost productivity. Also, the extent to which investment in training aimed to upskill human capital contributes to enhance industries' productivity remains often unassessed, also due to the inherent challenges related to measuring investment in this type of knowledge-based capital (KBC).

This work contributes to fill this gap by shedding light on the way cognitive and task-based skills (i.e. the skills that workers need to perform their job task; see Grundke et al. (2017 $\left.{ }_{[7]}\right)$ ) contribute to industries' innovation abilities and economic performance. Also, as training helps upskilling human capital (Destré, Lévy-Garboua and Sollogoub, $2008_{[8]}$ ), the analysis explores the way innovation output and different types of training relate to labour productivity, distinguishing between formal, informal and non-formal training (as defined in Squicciarini et al. $\left(2015_{[9]}\right)$ ). The analysis first explores these relationships through a simple Ordinary Least Square (OLS) regression model. It then implements a Heckman selection model to investigate causal links.

While the analysis builds on the existing literature that links human capital, innovation and growth at the aggregate level, it contributes novel evidence along several dimensions. Firstly, the importance of human capital is captured using survey based indicators of cognitive and task-based skills rather than broad measures of educational attainment, often used in existing studies (Griffith, Redding and Van Reenen, 2004 ${ }_{[10]}$; Vandenbussche, Aghion and Meghir, 2006 $[11]$; Mason, Rincon-Aznar and Venturini, 2019 $[3])$. Secondly, the paper takes into account the role of training in upskilling human capital and distinguishes between formal, informal and non-formal training. As skills can and should be nurtured, it is important not only to account for existing skill endowments but also for the upskilling taking place in industries, and to assess the way it contributes to enhance economic performance. Finally, while using patents as proxies of innovation, it focuses on the innovative ability of the whole economy, rather than focusing on manufacturing industries alone, as mostly done in the past (Crépon, Duguet and Mairesse, 1998 ${ }_{[1]}$; Sterlacchini and Venturini, 2014 $\left.{ }_{[12]}\right)$.

The results show that innovative outputs, investment in organisational capital (OC) and physical capital intensity (measured by net fixed assets) are positively and significantly related with labour productivity. Also, investment in training relates positively and significantly with labour productivity. When disentangling the different types of training, it becomes apparent that this effect is mainly driven by informal training.

Results for the cognitive and task-based skills variables are more mixed. Information and Communications Technology (ICT) skills relate positively to productivity when controlling for investment in informal training. The selection model lends further support to an additional indirect effect of ICT skills on productivity through innovation outputs. No significant correlation conversely is found between the cognitive skills variable (measured by numeracy) and productivity, nor between the STEM ${ }^{1}$ task-based skills and labour productivity. ${ }^{2}$ Finally, dispersion in cognitive skills, measured by the difference between 
8 | THE ROLE OF INNOVATION AND HUMAN CAPITAL FOR THE PRODUCTIVITY OF INDUSTRIES

the $10^{\text {th }}$ percentile and median numeracy score, has a positive and significant coefficient in the majority of the labour productivity models.

The reminder of the paper proceeds as follows. The next section frames the problem in existing literature by providing a review of findings on skills, training, innovation and labour productivity. The following section outlines how information on patents, skills and training is collected and outlines the empirical methodology devised. Section 4 presents country-industry-level evidence on the relationship between skills, training, innovation and productivity whereas section 5 concludes. 


\section{Chapter 2. Literature Review}

It is often argued that the knowledge and information possessed by its workforce is one of the most valuable assets of a firm (Bell, 1976 ${ }_{[13]}$ ) and that competitive advantages can be obtained through workers' skills $\left(\mathrm{OECD}, 2017_{[14]}\right)$ and maintained through new learning (Slater and Narver, $1995_{[15]}$; Woodruff, $\left.1997_{[16]}\right)$. Moreover, the link between human capital, innovation and labour productivity has long been acknowledged, although the vast literature focusing on this relationship mainly employs somewhat crude measures of both human capital and innovation.

The present paper builds upon these studies by combining a number of complementary strands of the literature, in the absence of a set of studies focusing on the overall relationship we are investigating. The literature strands we combine are those on labour productivity, on the role of innovation inputs and outputs, on education and skills, as well as on knowledge-based capital, such as investment in training and organisational capital. These different strands of the literature are approached in a systematic fashion, by first discussing the innovation and productivity literature, then the importance of absorptive capacity and Organisational Capital (OC) and, relatedly, of education and skills and ending by explaining the role of training.

\subsection{Innovation and Productivity}

While many aspects remain to be explored about the importance of skills for innovation, much more is known about the broader relationship between innovative activities and innovation output. Crépon et al. $\left(1998_{[1]}\right)$ were among the first to study the links between research effort, innovation output and productivity at the firm level, correcting for selectivity and simultaneity biases. They find that simultaneity tends to interact with selectivity and that therefore both biases must be controlled for together, using a structural model with equations for selection into engaging in $R \& D$ activities, expenditure in $R \& D$, innovation output and productivity. Crépon et al. $\left(1998_{[1]}\right)$ find that the innovation output of firms, measured by patents or innovative sales, increases with R\&D expenditures. They also find that firm productivity correlates positively with a higher innovation output, even when controlling for the skill composition of labour as well as for physical capital intensity.

Criscuolo $\left(2009_{[2]}\right)$ employs a similar three-stage methodology as Crépon et al. $\left(1998_{[1]}\right)$ and shows that investing in innovation is associated with 14-35 percent increase in sales from product innovation. Also, she finds that a 1 percent increase in product innovation is associated with 0.3-0.7 percent higher labour productivity.

Mason et al. (2019 $\left.9_{[3]}\right)$ also use a similar three-step model ${ }^{3}$ to study which skills contribute most to improve the absorptive capacity and productivity performance of firms. Absorptive capacity can be broadly intended a firm's ability to recognise, extract and assimilate value from new information, and apply it to commercial ends. They find important roles for both high-level skills and upper intermediate (technician-level type of) skills in converting the knowledge sourcing opportunities provided by openness into innovative output. In addition, they find that in countries near the technological frontier also the skills of the workforce as a whole are important for productivity growth.

This study uses a similar approach to Crépon et al. (1998 $\left.8_{[1]}\right)$, Criscuolo $\left(2009_{[2]}\right)$ and Mason et al. $\left(2019_{[3]}\right)$ to control for selection effects. The methodology employed in this paper uses R\&D expenditure as an exclusion restriction in a Heckman two-step model to control for selection into innovative industries. However, unlike these other studies that use firm- 
level data, this paper uses data at the country-industry level, and this level of aggregation, while able to deliver interesting results for policy, constrains our ability to implement more complex structural models.

Another group of studies investigates the relationship between investment in R\&D and economic performance using industry-level data for the manufacturing sector. Sterlacchini and Venturini $\left(2014_{[12]}\right)$ assess the relationship between R\&D capital and TFP across the manufacturing industries of Italy and Spain over the period 1980-2006 and find that also in countries classified as technology followers, $R \& D$ investment is a crucial condition to boost the productivity of manufacturing.

Rao et al. (2002 $\left.{ }_{[17]}\right)$ perform firm- and industry-level analyses of Canadian manufacturers. Controlling for a number of industry characteristics, they find inter-industry differences in labour productivity levels among Canadian manufacturing industries to be positively related to differences in capital intensity, $R \& D$ intensity and skills intensity. Skills intensity is here measured by both the proportion of workers with 1-3 years of non-university postsecondary education and the percentage of workers with a university degree.

\subsection{Absorptive Capacity and Organisational Capital}

One of the main mechanisms behind the human capital-innovation-productivity nexus is that training and better skills increase the absorptive capacity of firms. Absorptive capacity is a firm's ability to recognise the value of new information, assimilate it and apply it to commercial ends (Cohen and Levinthal, $1989_{[18]}$; Cohen and Levinthal, 1990 ${ }_{[19]}$ ). Zahra and George (2002 [20] $)$ further distinguish between "potential" and "realised" absorptive capacity. Potential absorptive capacity refers to the ability to recognise, acquire and assimilate useful external knowledge; and realised absorptive capacity refers to the ability to transform and apply acquired knowledge effectively within organisations (Mason, Rincon-Aznar and Venturini, 2019 $\left.{ }_{[3]}\right)$. These papers provide a conceptual framework about the mechanisms behind the empirical linkages between human capital, innovation and productivity, which we investigate.

Existing evidence further suggests that the absorptive capacity of firms is positively and significantly shaped by the knowledge infrastructure of the firm, by management support and by the relational capability of workers. Many studies have underlined the positive role of communication and interaction between workers on firm performance. Cooperation and interaction between employees result in fewer missed signals between employees, and reduce the time wasted carrying out redundant communications, searching for missing information, and waiting to hear from co-workers (Hamilton, Nickerson and Owan, $2003_{[21]}$; Gittell, Seidner and Wimbush, 2010 [22] $)$.

Absorptive capacity also contributes to explain part of the positive effect of R\&D on productivity, as investment in $R \& D$ enhances the ability of firms to absorb the possible knowledge spillovers that may exist (Cohen and Levinthal, $1989_{[18]}$ ). We take this indirect effect into account in the model by controlling for skills in the selection equation for (self) selection into innovative industries. We believe that to use R\&D expenditure as an exclusion restriction one needs controlling for the absorptive capacity of the sector. We capture this through a number of skill variables, as explained later, when describing the model.

In the present model we also take into account one of the key knowledge-based assets of firms and industries, i.e. their Organisational Capital (OC). OC ensures the long-term functioning of firms and helps workers deal with the inherent difficulties associated with everyday challenges as well as long-term strategies and decisions. These include innovation 
and technological change, as well as organisational change, and is therefore an important driver of firm value and economic growth (Francis, Mani and Wu, 2015 [23]).

However, measuring investment in $\mathrm{OC}$ remains challenging, which is reflected in the vast number of definitions and measurement approaches used in the literature. As explained, we here follow Squicciarini and Le Mouel $\left(2012_{[24]}\right)$, who define OC as the firm-specific organisational knowledge resulting from the performance of tasks affecting the long-term functioning of firms. These include: developing objectives and strategies; organising, planning and supervising production; and managing human resources. We rely on Squicciarini and Le Mouel's (2012 $\left.{ }_{[24]}\right)$ identification of occupations that perform OCrelated tasks and calculate the proportion of OC-workers at the industry level, as done in Cammeraat, Samek and Squicciarini (2021 $\left.{ }_{[25]}\right)$.

Not only the quantity of OC is important, but also the quality, i.e. the skill endowment of the workers performing OC-related tasks. Cammeraat, Samek and Squicciarini (2021 [25]) assesses the quality of $\mathrm{OC}$ at the country-industry level by looking at the skills of OC workers and compares it with the skills of the rest of the workforce, indicated as the nonOC related workforce. The study finds evidence of a "Lost in translation" type of effect, whereby relatively larger ICT skill gaps between OC and non-OC workers relate negatively to productivity. The study concludes that dispersion in task-based ICT skills may harm productivity, as it may hinder information flows and use. The study further finds that the task-based STEM skills of all workers are positively related with productivity, for non-OC especially those of OC-workers (Cammeraat, Samek and Squicciarini, 2021 ${ }_{[25]}$ ). This finding is in line with Peri, Shih and Sparber $\left(2015_{[26]}\right)$ who find that increases in STEM workers are associated with significant wage gains.

This work contributes to the studies mentioned above and to the policy discussion by studying the role of workers' skills for innovation and productivity. A special focus is on the role of organisational capital and training in shaping innovation and productivity patterns, as training represents investment in human capital aimed at enhancing workers' skills.

\subsection{Education, Skills, Innovation and Productivity}

$\mathrm{KBC}$ is increasingly recognised as an important source of labour productivity and economic growth (Jona Lasinio, Iommi and Manzocchi, 2010 [27]; Marrocu, Paci and Pontis, 2011 [28]; Corrado et al., 2012 $\left.2_{[29]}\right)$. A wide array of assets make up KBC (see Corrado et al, $\left(2005_{[30]}\right)$ ) and several of them shape or are part of innovative activities. It thus becomes important to look beyond the role of $\mathrm{R} \& \mathrm{D}$, when examining the relationship between innovation and productivity, and to take better into account the different KBC components. Among them, importantly, human capital, which is at the foundation of $\mathrm{KBC}$, as it may be understood as encompassing the knowledge and skills obtained through schooling, training and everyday experience (De la Fuente and Ciccone, $2003_{[31]}$ ). These activities are not only useful in the production of goods, services and further knowledge (see also Wright and McMahan (2011 $\left.{ }_{[32]}\right)$, about human capital) but are also essential for innovative activities.

Most comparative studies on the links between skills, innovation and economic growth have been performed at the country or country-industry level and have measured skills in a somewhat general fashion, i.e. as the proportion of employees with tertiary education (Griffith, Redding and Van Reenen, 2004 ${ }_{[10]}$; Vandenbussche, Aghion and Meghir, $2006_{[11]}$; Mason, Rincon-Aznar and Venturini, 2019 ${ }_{[3]}$. These studies generally find the level of education to be important for innovation and growth. While essential for a better understanding of the links at hand, some of these studies may suffer from reverse causality issues. They may in fact be capturing the effect of economic performance on innovation 
activity, rather than the effect of innovation on economic performance - that is, the focus of the present analysis.

Vandenbussche, Aghion and Meghir $\left(2006_{[11]}\right)$ argue that technologically advanced countries are more likely to engage in innovation (which requires high-level skills) than they are to imitate innovators (for which relatively lower levels of skills may suffice). They also find that multi-factor productivity (MFP) growth is positively related to the interaction between proximity to the technological frontier and high-level (tertiary) skills, but not low skills. This implies that high skills are needed to take advantage of being closer to the technological frontier. Ang and Madsen $\left(2014_{[33]}\right)$ further find that the relationship between tertiary education and proximity to the technological frontier in OECD countries is strengthened by the contributions made by older tertiary-educated workers. This perhaps reflects the value of experience and of crystallised knowledge of older workers, relative to younger workers, whose strengths mainly lie in fluid intelligence (Salthouse and Maurer, $\left.1996_{[34]}\right)$.

A limitation of using tertiary education to proxy skills is that this corresponds to making the implicit assumption that education always succeeds in building human capital and that all skills matter to the same extent. No information is in fact provided about the different skills that may be important for innovation, despite increasing evidence showing that intermediate-skill workers and uncertified skills are also important for innovation and growth (Mason, O'Leary and Vecchi, 2012 $\left.2_{[35]}\right)$. Also the interdependence between highlevel skills and other skills is important (CEDEFOP, 2014 $\left.{ }_{[36]}\right)$. For example, technicians are key in product design and development, as are craft-skilled workers in improving production processes (Mason and Wagner, 2005 [37]; CEDEFOP, 2014 ${ }_{[36]}$ ). Recent evidence for Swiss manufacturing firms further suggests that a strong presence of apprentice-trained workers alongside university graduates can also contribute to product innovation (Bolli, Renold and Wörter, 2017 [38]). Also Mason et al. (2019 $\left.{ }_{[3]}\right)$ shows that innovation output increases not only with high and upper intermediate skills, but is also positively related to the skills of the workforce as a whole.

In addition to skill levels, skill types matter, and do so importantly. Cognitive skills are a key driver of innovation and technology diffusion (Messinis and Ahmed, 2013 ${ }_{\text {[39] }}$ ), and ICT and STEM skills are considered important for innovation and productivity (Hall, Lotti and Mairesse, 2013 ${ }_{[40]}$; Peri, Shih and Sparber, 2015 [26] $)$. Toner $\left(2011_{[41]}\right)$ investigates the type of skills that top innovating firms look for and finds large variation in the type of skills profiles recruited by different industries. Toner $\left(2011_{[41]}\right)$ further finds that higher skills translate into more innovation and growth, by both accelerating technological change and by making firm able to adapt to change. Furthermore, education, training and innovation emerge as complements, as are capital investment and skills. Finally, a number of studies also look at the importance of skills for the probability to innovate and find that skills (or rather, lack thereof) are one of the most important obstacles to innovation in a wide range of industries and countries (Mohnen and Röller, 2005 $5_{[42]}$ ).

We build on these groups of studies and add to them by using measures of task-based skills such as ICT, STEM, communication and organisational skills to better assess the role played by different skills with respect to innovation and economic performance.

\subsection{The Importance of Training}

Although the stock of educated workers has contributed to labour productivity over the past 50 years, growth in human capital stock is expected to slow down (Braconier, Nicoletti and Westmore, 2014 ${ }_{[43]}$ ) making it increasingly important to efficiently deploy the existing stock. Also, as the global economy becomes increasingly competitive and technology- 
based, new skills are required on the job. Work-related training can help reduce the gap between skills supply and demand by firms (Acemoglu and Pischke, 1999 [44]; Arulampalam, Booth and Bryan, 2004 [45]; Tikkanen, Hovdhaugen and Støren, 2018 [46] and help reduce mismatch on the labour market (van Smoorenburg and van der Velden, $\left.2000_{[47]}\right)$.

Existing studies generally find large positive effects of training on productivity (Blundell et al., 2005 ${ }_{[48]}$; Bassanini et al., 2005 [49]; Frazis and Loewenstein, 2005 [50]; Conti, 2005 [51]; Zwick, 2006 $[52]$; Dearden, Reed and Van Reenen, 2006 ${ }_{[53]}$; Almeida and Carneiro, 2009 [54]; Colombo and Stanca, 2014 ${ }_{[55]}$; Konings and Vanormelingen, 2009 $\left.9_{[56]}\right)$ which are similar in magnitude to investments in physical capital or schooling. There are numerous explanations for these findings.

Firstly, more skilled and experienced workers, so "better" human capital, often make better decisions. Secondly, learning-by-doing is expected to happen more if human capital is well endowed. Thirdly, innovation and technology adoption can be facilitated by suitable workers' training.

For instance, Boothby et al. (2010 $\left.0_{[57]}\right)$ find that firms that adopt advanced technologies together with providing strategic training (types of training whose provision is most influenced by the technology) are, on average, more productive than other technology adopters who do not train. In turn, the latter are more productive than those who do not use advanced technologies. Also, a strong link seems to exist between training and the propensity to innovate and innovative output (Bauernschuster, Falck and Heblich, 2009 [58]; Gallié and Legros, 2011 $1_{[59]}$; González, Miles-Touya and Pazó, 2016[60]; Dostie, 2017[61]).

However, due to the difficulty related to measuring investment in training, existing work often employs somewhat simple measures of training, and seldom the cost of training (Bartel, 1994 ${ }_{[62]}$; 2000 [63]; Barrett and O'Connell, 2001 ${ }_{[64]}$; Conti, 2005 ${ }_{[51]}$; Dearden, Reed and Van Reenen, 2006 $[53]$ ), which means that estimates cannot be interpreted as rates of returns (Mincer, 1989 [65]; Machin and Vignoles, 2001 ${ }_{[66]}$; Nilsson, 2010 [67] $)$. Almeida and Carneiro $\left(2009_{[54]}\right)$ argue that information on direct costs of training are essential, as estimates of the return to training will otherwise be too high since direct costs account for the majority of training costs.

Even when costs are captured, they often do not distinguish between different training types, despite formal and informal training impacting differently on productivity (Black and Lynch, 1996 $6_{[68]}$; Barrett and O'Connell, 2001 ${ }_{[64]}$; Zwick, 2005 [69]; Dostie, 2013 ${ }_{[70]}$ ). Exceptions to this are Werquin $\left(2007_{[71]}\right)$ and Squicciarini et al. (2015 $[9]$, who do distinguish between different training types, but differ in their definitions of less formal learning types ${ }^{4}$.

Nonetheless, numerous scholars have stressed the importance of training for human capital formation (Barron, Black and Loewenstein, 1989 ${ }_{[72]}$; De Grip and Sauermann, 2012 ${ }_{[73]}$ ). Also, as the amount of on-the-job training offered by firms can far exceed the extent of classroom training (Pischke, $2005_{[74]}$ ), it may have a larger impact on a firm's propensity to innovate. Dostie $\left(2017_{[61]}\right)$ finds that both classroom and on-the-job training have a positive impact on workplace-level innovation performance and that, for many types of innovation, on-the-job training has as much impact on innovation performance as does classroom training.

Recently, the transfer of learning outcomes at the individual level in the work context, rather than training itself, gained more attention because of its contribution to a firm's performance (Holton, Chen and Naquin, 2003 ${ }_{[75]}$ ). These training transfers nevertheless depend on the work environment, such as managerial support (Holton, Chen and Naquin, $2003_{[75]}$; Campbell, 2006 $6_{[76]}$ ) or participants' and peers' characteristics (Baldwin and Ford, 
$1988_{[77]}$; Nikandrou, Brinia and Bereri, $\left.2009_{[78]}\right)$. Work environments where workers have more autonomy and work in teams nurture a training culture that yields high returns (Fialho, Quintini and Vandeweyer, 2019 ${ }_{[79]}$ ). Empirical evidence on the relationship between knowledge acquisition and its impact on internal capabilities remains nevertheless scarce (Sinkula, 1994[80]; Morgan, Katsikeas and Appiah-Adu, 1998 ${ }_{[81]}$; Destré, LévyGarboua and Sollogoub, 2008 $\left.{ }_{[8]}\right)$.

We add to the discussion on organisational learning ${ }^{6}$ by examining the role of investments in less formal training, e.g. through learning-by-doing and between peers. Most of this empirical work commonly uses data on wages (Bartel, 1995 $[82]$; Arulampalam, Booth and Elias, 1995 [83]; Frazis and Loewenstein, 2005 [50]; Almeida and de Faria, 2014 ${ }_{[84]}$ ), but these do not necessarily reflect the marginal product of workers in an imperfect labour market, and therefore cannot assess the effect of training on labour productivity ${ }^{7}$. We contribute by estimating the returns of training to labour productivity, rather than wages, by employing investment estimates. Secondly, we employ estimates of investments in training and distinguish between formal, informal and non-formal training. Finally, we examine this link at the industry-level rather than the firm-level to capture possible externalities, such as spillovers, from training (Dearden, Reed and Van Reenen, 2006 ${ }_{[53]}$ ). 


\section{Chapter 3. Methodology}

\subsection{Conditional Correlations}

The relationship between innovative output (proxied by patents), human capital (proxied by task-based as well as cognitive skills), training, OC and labour productivity is explored using OLS regression models at the country-industry level. The paper uses the log of labour productivity, $L P$, in value added terms (i.e. value added in USD per million employees) as the dependent variable:

$$
\begin{gathered}
\ln (L P)_{i, k}=a_{0}+a_{1} \ln (\text { patents })_{i, k}+a_{2} \overline{I C T}_{i, k}+a_{3} \overline{S T E M}_{i, k}+a_{4} \text { numeracy }_{i, k}+ \\
a_{5} \text { numeracy_dif } f_{i, k}+a_{6} \ln (\text { training })_{i, k}+x_{i, k}^{\prime} \beta+\mu_{\mathrm{j}}+\delta_{\mathrm{c}}
\end{gathered}
$$

For country $i$, industry $k$, country cluster $j$ and industry cluster $c^{8}$.

In order to capture innovative output, patents, information on IP5 patent families is collected from the European Patent Office (EPO) Worldwide Patent Statistical Database

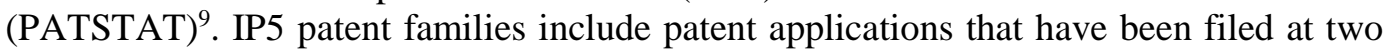
different IP offices worldwide, of which at least one is an IP5 office, i.e. namely the EPO, the Japan Patent Office (JPO), the Korean Intellectual Property Office (KIPO), the State Intellectual Property Office of the People's Republic of China (SIPO) and the USPTO.

The number of patent applications at the industry-country level is obtained by matching patent applicant names to the industry classification provided in the company-level data Bureau van Dijk, ORBIS. This indicator is then transformed in four steps: firstly, to take into account the fact that a remaining proportion of patents cannot always be matched, the number of successfully matched patent applications is weighted by the country-specific matching rate. Secondly, to further take into account different industry sizes, the weighted patent application count is also divided by the industry-country specific employee size (in million). Thirdly, the $\log$ is taken to aid interpretation of the resulting coefficients. Finally, the top and bottom 1 percent of patent values are winsorised ${ }^{10}$.

The independent variables $\overline{I C T}$ and $\overline{S T E M}$ represent the mean ICT and STEM skill score, respectively, at the country-industry level. Cognitive skills and their dispersion, and therefore a general measure of fundamental skills, are accounted for using numeracy skills ${ }^{11}$. The dispersion is captured by using median numeracy skill scores, numeracy, together with the difference between the numeracy skill score of the top 10 percentile and the median numeracy skill score, numeracy_dif. By including the latter variable in the model, we account partly for the dispersion and hence include the median, rather than the mean, value of the numeracy skill score in the model. Since the mean already provides distributional information implicitly, we use that for the ICT and STEM skill scores.

Numerous surveys find cognitive skills to be highly correlated with one another (OECD, $\left.2016_{[85]}\right)$. Numeracy appears to be most relevant for the accumulation of ICT and STEM skills and the development of patents and therefore, literacy, which is also measured in the Programme of the International Assessment of Adult Competencies (PIAAC), is excluded from this model $^{12}$. To facilitate comparison of the skill related coefficients, all skill indicators are rescaled and defined following a 0 to 100 scale. 
Another crucial component of the paper explores how nurturing and enhancing skills through formal schemes or on the job training, correlates with labour productivity. We employ the log of investment in firm-relevant training (i.e. investment in USD per million employees), training, following Squicciarini et al. (2015[9] $)$, who exploit a number of industry and country-level data sources in addition to individual-level PIAAC data to estimate investment in training (including opportunity costs of training) at the countryindustry level. They distinguish between formal, non-formal and informal training. Formal training refers to training taking place in an organised, outside-work environment, and aiming at the attainment of a degree at an education institution. Therefore, it captures general investments in human capital. Non-formal training is a structured type of training that may take place both inside and outside a company and during or outside working hours but it does not typically lead to the attainment of an education degree. Finally, informal training results from the daily activities of employees at the workplace, and can be understood as learning by doing or learning from peers and/or supervisors.

It is important to account for all three types because they are likely to be highly complementary and omitting one may lead to overestimating the role of the others. This is particularly relevant for informal training, which is rarely included due to difficulties with data availability and heterogeneity across countries. Engaging more in formal and nonformal training may in fact increase employees' participation in informal learning as well, enhance their absorptive capacity and increase the prospect returns of investing in such training.

Therefore, we not only use the sum of investment in all training types, done using training in equation (1), but also include each type individually to disentangle their individual contribution to labour productivity. The latter is done in equation (2) and is captured by formal, nonformal and informal.

$$
\begin{aligned}
\ln (L P)_{i, k}= & a_{0}+a_{1} \ln (\text { patents })_{i, k}+a_{2} \overline{I C T}_{i, k}+a_{3} \overline{\text { STEM }}_{i, k}+a_{4} \text { numeracy }_{i, k}+a_{5} \text { numeracy }_{-} \text {dif }_{i, k}+ \\
& a_{6} \ln \left(\text { formal }_{i, k}+a_{7} \ln (\text { nonformal })_{i, k}+a_{8} \ln \left(\text { informal }_{i, k}+x_{i, k} \beta+\mu_{\mathrm{j}}+\delta_{\mathrm{c}}\right.\right.
\end{aligned}
$$

In addition, and to account for a number of factors known to shape innovative output and economic performance, the proposed models also feature physical capital intensity and the proportion of OC staff, both at the country-industry level. The former is measured as net fixed assets, $N F A$, in thousands USD per worker (in log terms) obtained from the OECD's Annual National Accounts database. The latter is the proportion of OC-relevant occupations in total employment obtained from PIAAC, OCshare. OC-relevant occupations were identified in Cammeraat, Samek and Squicciarini $\left(2021_{[25]}\right)$ who build on work carried out by Le Mouel and Squicciarini $\left(2015_{[86]}\right)$.

Ideally, the regressions would need to include individual country $\mu_{\mathrm{i}}$ and industry $\delta_{\mathrm{c}}$ fixed effects (FE), to control for unobserved characteristics at the country and the industry level, respectively. By controlling for unobserved country characteristics (that are similar across industries), the analysis takes into account cultural differences known to affect organisational and managerial practices (Bloom and Van Reenen, 2010 ${ }_{[87]}$; Bloom, Sadun and Van Reenen, 2012 $2_{[88]}$. The use of industry dummies, in addition, helps shedding light on how changes in skills within each industry relate to innovative activities and labour productivity. However, due to a relatively small sample size and thus small cell sizes, using individual country and industry FE simultaneously absorbs too many degrees of freedom, risking overfitting the model. We thus rely on clustered FE to reduce the number of variables in the model. 
Countries are clustered based on their similarity with respect to their overall skills profile. The related dendogram is provided in Figure A.1. Industries are aggregated at the section (one-digit) level and sometimes even further. The resulting clusters are presented in Table 3.1.

Table 3.1. Country and industry clusters

\begin{tabular}{|c|c|c|}
\hline & Countries & Industries \\
\hline Cluster 1 & Canada, France, Great Britain, Ireland, United States & Agriculture, forestry and fishing (A); mining and quarrying (B) \\
\hline Cluster 2 & Denmark, Finland, Norway, Sweden & $\begin{array}{l}\text { Food and textile (CA \& } \mathrm{CB}) \text {; chemicals and metals }(\mathrm{CC}-\mathrm{CH}) ; \mathrm{PC} \text {, } \\
\text { machinery and repairs }(\mathrm{Cl}-\mathrm{CM})\end{array}$ \\
\hline Cluster 3 & $\begin{array}{l}\text { Austria, Belgium, Czech Republic, Estonia, Germany, } \\
\text { Netherlands, Poland }\end{array}$ & Utilities (D \& E); construction (F) \\
\hline Cluster 4 & Italy, Slovakia & $\begin{array}{l}\text { Information and communication }(\mathrm{J}) \text {; financial and insurance } \\
\text { activities }(\mathrm{K})\end{array}$ \\
\hline Cluster 5 & Korea, Japan & Public services ( $O \& P \& Q)$ \\
\hline Cluster 6 & & $\begin{array}{l}\text { Wholesale, retail, transport, storage, accommodation and food } \\
\text { (G \& H \& I); real estate activities (L); other business services } \\
\text { (M\&N); other social/personal services (R\&S) }\end{array}$ \\
\hline
\end{tabular}

Source: Authors' own compilation based on PIAAC data and following Bechichi et al. (2018[89])

Country-industry cells based on fewer than 20 observations in PIAAC are imputed (where possible) or otherwise excluded from the analysis, to reduce possible measurement error in the skill variables. Robust standard errors are clustered at the country level.

\subsection{Exploring Causal Relationships}

The model is likely to suffer from selection bias and endogeneity. Firstly, individuals with higher skills may self-select into larger firms that tend to be more innovative and also more productive, introducing possible selection biases. Evidence suggests that large firms offer career prospects and fringe benefits attracting better-educated school leavers in particular (Wagner, 1999 $9_{[90]}$ ), while small firms cannot offer comparable prospects and experience marginal labour markets (Kelliher and Reinl, 2009 ${ }_{[91]}$ ). Secondly, there is evidence that more productive firms tend to be larger and provide formal training more frequently (Kotey and Folker, 2007 ${ }_{[92]}$; Kim and Yoon, 2008 ${ }_{[93]}$; World Bank, 2010 ${ }_{[94]}$; Cunningham and

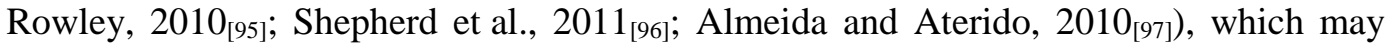
introduce reverse causality into the models. This does not mean that small firms do not offer any training but they rather rely on informal processes to develop skills (Ashton, $2008_{[98]}$; Kitching, 2008 ${ }_{[99]}$; Bishop, 2012 $\left.{ }_{[100]} ; 2017_{[101]}\right)$. At the same time, larger and more innovative firms may be able to free up more resources for investment in training. Finally, if other unobserved factors that affect both, skills, innovation and productivity, such as socio-economic background, perceived opportunities and social expectations, are omitted from the model, estimates may suffer from omitted variable bias.

The paper attempts to control for these different sources of endogeneity by implementing a Heckman selection model using a probit model (Heckman, 1979 $\left.{ }_{[102]}\right)$, as shown in equation (3).

$$
\begin{gathered}
\text { Prob(top } 40=1 \text { |patents, ICT, STEM, numeracy, numeracy_dif, training, } R \& D, x) \\
=a_{0}+a_{1} \ln (\text { patents })_{i, k}+a_{2} \overline{I C T}_{i, k}+a_{3} \overline{S T E M}_{i, k}+a_{4} \text { numeracy }_{i, k}+a_{5} \text { numeracy_dif }_{i, k}+ \\
a_{6} \ln (\text { training })_{i, k}+a_{7} \ln (R D)_{i, k}+x_{i, k}^{\prime} \beta+\mu_{\mathrm{j}}+\delta_{\mathrm{c}}
\end{gathered}
$$


Ideally, we would need a binary variable for the selection model that distinguishes between firms that engage in innovative activities and those that do not, but this information is not available for two reasons. Firstly, we know the number of patent applications at the country-industry level but firms may engage in innovative activities that result in outputs other than patents, e.g. trademarks or even trade secrets. Additionally, not all patents can be matched, so that some firms may falsely be identified as non-innovators. Secondly, we use data at the industry- rather than the firm-level and, hence, the aggregation level may hide a lot of heterogeneity.

As a result, we construct a binary indicator, top40, as the dependent variable in the selection model that distinguishes between "high" and "medium to low" innovating industries within countries. Industries within a country are identified as high-innovators and, therefore, coded one, if the number of patents within this industry exceeds the top 40 percentile in that particular country. All other industries in that country are coded zero ${ }^{13}$. We use the top 40 percentile threshold for both theoretical and practical reasons. The theoretical reason is that the median or mean is too restrictive as we expect innovation intensity to be much higher for a smaller proportion of industries, which also follows from the histogram shown in Figure A.2. At the same time, considering only the top quarter of the distribution would drop a lot of the observations in the selection model as many industries would be defined as low innovation intensity industries across all countries. Considering this trade-off, between a smaller proportion of high innovation intensity industries and a larger number of observations, it is preferable to use the top 40 percentile to define the selection dummy.

The model is estimated using the log of $\mathrm{R} \& \mathrm{D}$ expenditure as the exclusion restriction, $R D$. Albeit it is possibly a strong assumption, we assume that R\&D only affects labour productivity through the innovative output, here patents, that result from R\&D. However, although $R \& D$ expenditure is an input to the innovation process, we understand that firms, especially small in size and in the service sector, engage in less formal innovative activities, which R\&D expenditure is less likely to capture. Controlling for skills in both the selection model and the productivity model is thus important to control for the absorptive capacity effect of $R \& D$ on productivity (possible indirect effect), while exploiting $R \& D$ as an exclusion restriction on the probability of being an innovative industry. ${ }^{14}$

From this first step the Inverse Mills Ratio (IMR), $\lambda$, is estimated and used as an additional regressor in the second step to control for selectivity. This is shown in equation (4) below.

$$
\begin{gathered}
\ln (L P)_{i, k}=a_{0}+a_{1} \ln (\text { patents })_{i, k}+a_{2} \overline{I C T}_{i, k}+a_{3} \overline{S T E M}_{i, k}+a_{4} \text { numeracy }_{i, k}+ \\
a_{5} \text { numeracy_dif } f_{i, k}+a_{6} \ln (\text { training })_{i, k}+a_{7} \hat{\lambda}_{i, k}+x_{i, k, t}^{\prime} \beta+\mu_{\mathrm{j}}+\delta_{\mathrm{c}}
\end{gathered}
$$




\section{Chapter 4. The Relationship between Skills, Training, Innovative Output and Productivity}

\subsection{Descriptive Statistics}

While there is ample evidence showing positive correlations between our variables of interest, it is helpful to statistically characterise each of these, especially in relation to labour productivity, before assessing the relationship econometrically.

Table 4.1 shows the descriptive statistics of the variables from the regression model, all constructed at the country-industry level. The first column shows the variable name and the following four columns present the mean, the standard deviation, the minimum and the maximum values, respectively.

Here we focus on the main variables of interest, mainly, labour productivity, patents, skills, the proportion of OC staff in the workforce and investment in training. As already mentioned, the log of labour productivity is measured in value added terms in USD per million employees. Using the log of relatively large numbers explains the relatively high mean and low standard deviation that are observed in Table 4.1. The log is taken to aid the interpretation of the correlation coefficients in the regression results and present them in terms of percentage change.

The patent indicator measures the number of patents at the country-industry level weighted by the country-industry specific matching rate, adjusted by the industry-country specific employee size (in million) and winsorised (top and bottom 1 percent). It appears that the number of patents varies greatly across the observations in our sample. This is no surprise since, even though our data is at the aggregated country-industry level, there is a lot of variation in the extent to which innovative output is produced, not only at the firm-level, but even by different industries and countries.

All our skill scores are measured on a 0-100 scale, so that country-industry comparisons between the different types of skills endowments can be made. On average, we observe higher cognitive (here measured by numeracy skills) and ICT skill scores than STEM skill scores for the country-industry observations in our sample. However, the endowment of cognitive skills is more similarly distributed across the observations in our data, while more variation emerges with regards to STEM skills and even more ICT skills.

On average, almost one third of the workforce in our sample are OC-related workers. However, this proportion varies greatly across industries and to a somewhat lesser extent across countries: it can go as high as two thirds of the workforce or as low as only 3 percent. While agriculture stands out for its low average share of OC-related workers ( 7 percent), the education sector has a particularly high proportion of OC-related workers (53 percent). Across countries, Norway has the highest average share of OC-related workers ( 38 percent) and Korea the lowest (19 percent).

Finally, it appears that investment in formal and non-formal training are, on average, higher than investment in informal training in our sample. However, at the same time investment in formal training is slightly more dispersed in our sample compared to the other types of training.

In our selection model, we also make use of a binary variable that identifies the industries within countries that have sufficient patents application to be in the top 40 percentile of the patent distribution. Therefore, by definition, the mean of this binary variable is 0.4 percent 
and it ranges from 0 to 1 . We also use log of $\mathrm{R} \& \mathrm{D}$ expenditure as an exclusion restriction, which appears to vary greatly across our observations.

\section{Table 4.1. Descriptive statistics of variables from the regression models}

\begin{tabular}{|c|c|c|c|c|}
\hline Variables & Mean & Std. dev. & Min & Max \\
\hline Log of labour productivity (value added, USD per million employees) & 25.33 & 0.73 & 23.63 & 28.27 \\
\hline Log of patents (patents/matching rate, per million employees) & 4.84 & 1.74 & 0.86 & 9.00 \\
\hline Numeracy skill score & 55.99 & 3.45 & 48.10 & 64.76 \\
\hline Median numeracy skills score & 56.59 & 3.46 & 48.29 & 64.69 \\
\hline Difference between top 10 percentile and median numeracy skill score & 10.73 & 1.36 & 4.61 & 15.82 \\
\hline ICT skill score (task-based) & 55.34 & 10.87 & 32.43 & 75.36 \\
\hline STEM skill score (task-based) & 51.02 & 6.18 & 38.16 & 70.89 \\
\hline Log of net fixed assets & 25.56 & 1.40 & 23.06 & 30.89 \\
\hline Proportion of OC workers & 30.14 & 15.30 & 2.76 & 66.06 \\
\hline Log of training investment (USD per million employees) & 22.50 & 0.81 & 20.22 & 24.40 \\
\hline Log of formal training investment (USD per million employees) & 21.55 & 1.18 & 16.23 & 23.91 \\
\hline Log of non-formal training investment (USD per million employees) & 21.46 & 0.77 & 18.67 & 23.01 \\
\hline Log of informal training investment (USD per million employees) & 20.73 & 0.70 & 18.34 & 22.50 \\
\hline Innovator dummy* & 0.40 & 0.49 & 0 & 1 \\
\hline Log of R\&D (USD per million employees)* & 19.32 & 2.70 & 12.00 & 24.21 \\
\hline
\end{tabular}

Note: These numbers are based on a sample size of 263 observations unless otherwise stated. * Variables used in the selection model have a smaller sample size of 222 observations.

Source: Authors' own compilation.

Figure 4.1 shows the relationship between patents and labour productivity. Each dot represents the country-industry's average log number of patents (based on our patent indicator) and log productivity level. The colours of the dots reflect the industry-cluster while the trend line depicts the predicted productivity from a linear regression of productivity on patents. Based on the upward sloping trend line, we can see immediately that there is a positive relationship between patents and productivity, a fact that is consistent with existing literature ${ }^{15}$. This positive relationship is also confirmed by the positive correlation coefficient of 0.36 in the correlation matrix in Table A.1. Manufacturing (C) tends to be the industry exhibiting the highest number of patents and relatively high labour productivity in most countries, and the data points resemble the predicted line relatively well.

Industry clusters that seem to outperform the predicted productivity - i.e. those that, with a given number of patents, display higher productivity than predicted - are IT, finance and insurance (J\&K) as well as agriculture (A) and mining (B). A similar observation can be made for utilities (D\&E) and construction (F) in the majority of countries. 


\section{Figure 4.1. Scatter plot: relationship between patents and labour productivity}

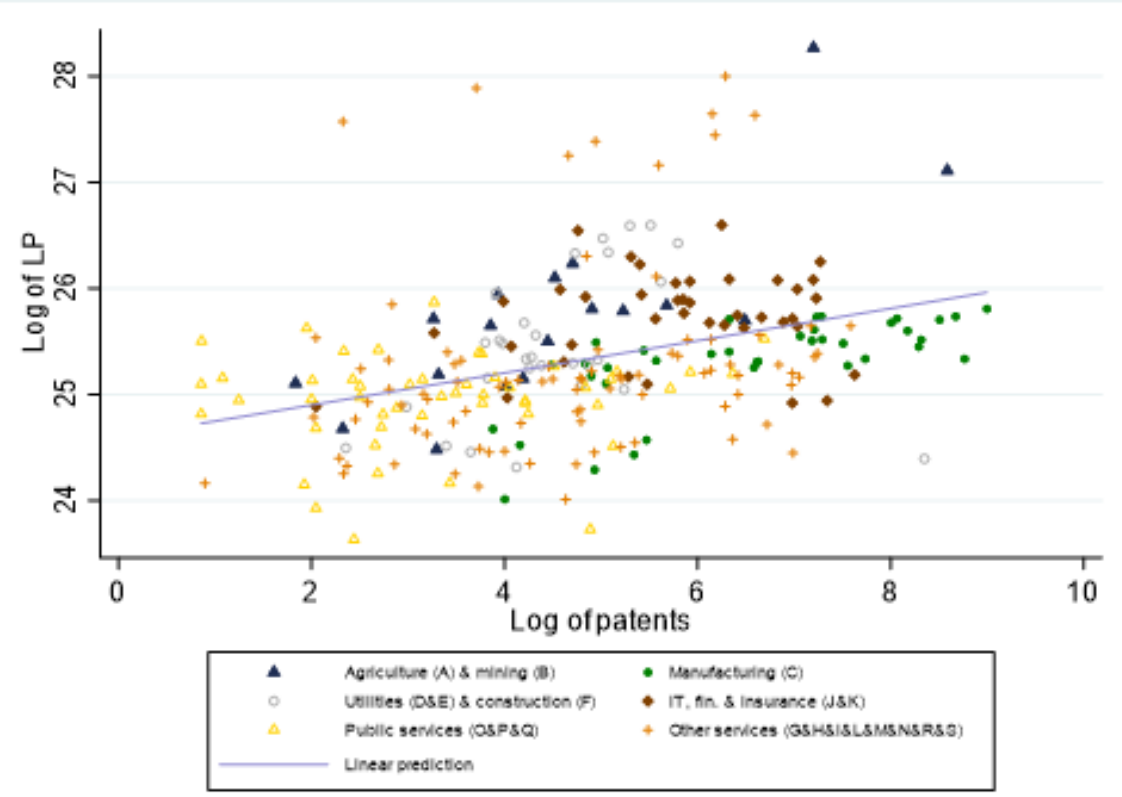

Note: The patent indicator measures the number of patents at the country-industry level weighted by the country-industry specific matching rate, adjusted by the industry-country specific employee size (in million) and winsorised (top and bottom 1 percent).

Source: Author's own compilation.

Similarly to Figure 4.1, Figure 4.2 shows the relationship between log of investment in total training and log of labour productivity. Again, an upward trend emerges, suggesting the two to be positively related. When looking more closely at the different industry clusters and comparing them with the pattern observed in the previous figure, we can see that they are more equally dispersed around the trend line, with less segmentation between the individual clusters. So given their investment in training, IT, finance and insurance (J\&K), agriculture (A) and mining (B) as well as utilities (D\&E) and construction (F) tend to be as productive as the simple linear regression predicts. There are some outperforming cases as is also visible in Figure 4.1, most noticeably in the agriculture (A) and mining (B) cluster, where given the investment in training, productivity is higher than predicted.

Due to the increasing importance of informal training, which encompasses learning-bydoing, interactions with peers and supervisors, among many others, we also show its relationship with labour productivity in Figure $4.3^{16}$. It should come as no surprise that an upward trend also emerges from Figure 4.3, implying that productivity increases with investment in informal training ${ }^{17}$. However, the line is steeper than in the other training chart, suggesting that informal training increases productivity more than an equivalent investment in formal or non-formal training.

By looking only at investment in informal training, rather than training as a whole, industry clusters become slightly more segregated again. For instance, IT, finance and insurance $(\mathrm{J} \& \mathrm{~K})$ is characterised by high investments in training and high productivity, while manufacturing $(C)$ and public services $(O \& P \& Q)$ tend to have moderate investments in training and productivity. The division of under- and over-performing industry clusters remain: public $(\mathrm{O} \& \mathrm{P} \& \mathrm{Q})$ and other business services generally exhibit lower productivity and IT, finance and insurance (J\&K), agriculture (A) and mining (B) as well as utilities $(\mathrm{D} \& \mathrm{E})$ and construction $(\mathrm{F})$ higher productivity with a given investment in informal training. 
Figure 4.2. Scatter plot: investment in total training and labour productivity

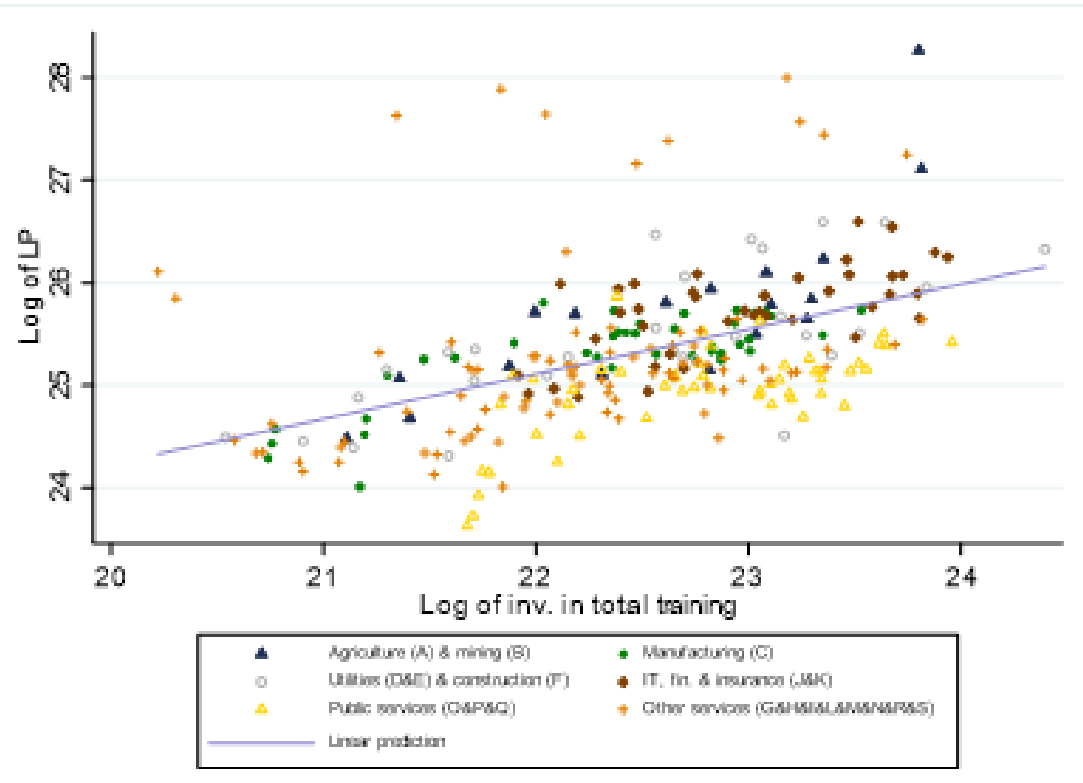

Note: Note: The sample consists of 263 observations with the following 20 countries included: AUT, BEL, CAN, CZE, DEU, DNK, EST, FIN, FRA, GBR, IRL, ITA, JPN, KOR, NLD, NOR, POL, SVK, SWE and USA.

Source: Author's own compilation.

Figure 4.3. Scatter plot: investment in informal training and labour productivity

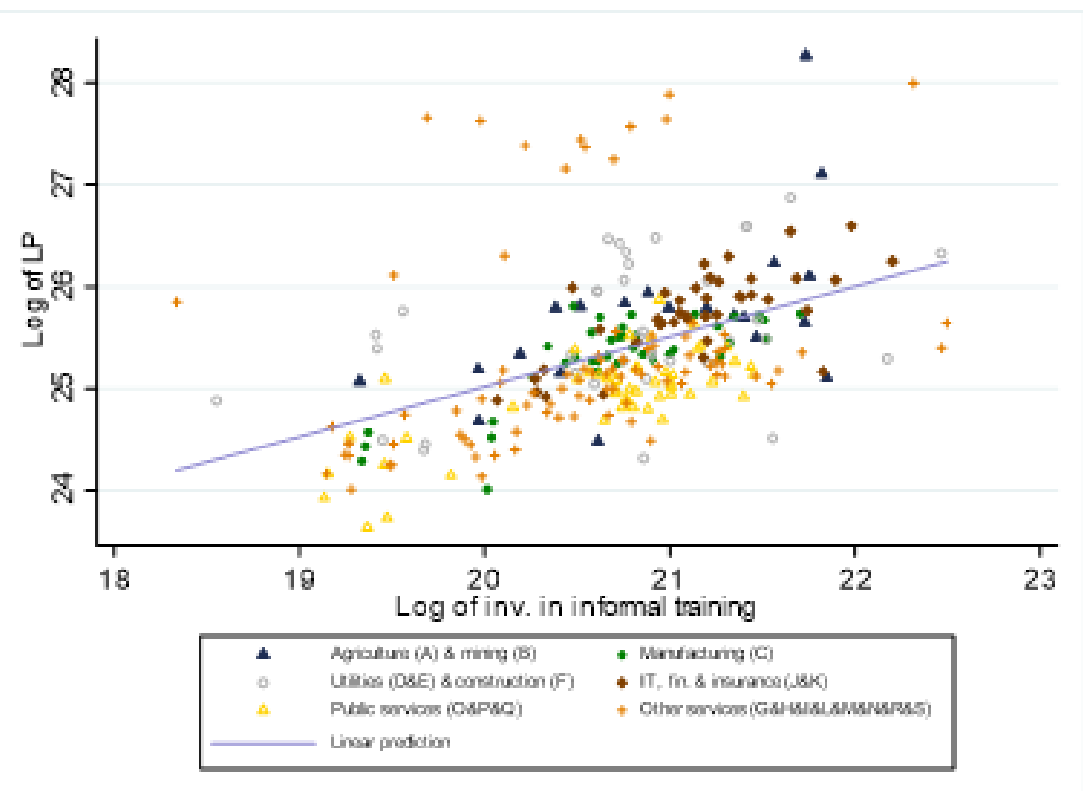

Note: The sample consists of 276 observations with the following 20 countries included: AUT, BEL, CAN, CZE, DEU, DNK, EST, FIN, FRA, GBR, IRL, ITA, JPN, KOR, NLD, NOR, POL, SVK SWE and USA. Source: Author's own compilation. 


\subsection{Regression Results}

We here present the results of the regression assessing the relationships between patents, skills, training and labour productivity, while controlling for the proportion of OC workers, net fixed assets and unobserved country cluster ${ }^{18}$ and industry cluster ${ }^{19}$ characteristics. ${ }^{20}$

As explained, we examine these relationships first through conditional correlations getting at simple relationships and then trying to address potential selectivity issues. The selection model uses $R \& D$ expenditure as the exclusion restriction to estimate the probability of being an innovating industry. To help the reader we first guide the reader through the layout of the results and then discuss these jointly.

Table 4.2 shows the conditional correlations between these variables including different training variables capturing total, formal, non-formal and informal training. The main purpose of this table is to disentangle the overall measure of investment in training to study if the strong positive correlation between training and productivity is driven by all or by only a specific type of training. The first column includes total investment in training. The following three columns (column 2 to column 4) present the results obtained when investment in formal training, non-formal training and informal training is controlled for, respectively. In the last column, we add all three types of training simultaneously.

Table 4.3 goes beyond conditional correlations and shows the results obtained when addressing selectivity. Each column, in Table 4.3, denoted (a) presents the selection model while columns labelled (b) present the labour productivity estimates. Equally to the previous table, we first control for investment in overall training and then for each type of training individually. Therefore, results in columns (b) of this table are comparable to the results shown in the previous table, with the difference that here the models address potential selection bias.

We generally find that the majority of our variables of interest are significant and positively correlated with labour productivity. These include innovation output, the proportion of OC workers and investment in training. There is also consistent evidence that productivity increases significantly with physical capital intensity: a one percent increase in patents relates to a 0.04-0.06 percent increase in labour productivity and a one percentage point increase in the proportion of $\mathrm{OC}$ workers relates to $0.003-0.005$ percent higher productivity. A one percent increase in net fixed assets is even related to a $0.37-0.39$ percent increase in productivity.

For investment in training, a large positive and statistically significant relationship emerges between total training (combining formal, non-formal and informal training) and labour productivity. This is of similar magnitude regardless of whether selection is addressed or not. Thus, a one percent increase in total investment in training is related to a 0.21 percent higher productivity in our OLS model presented in Table 4.2 and 0.19 percent higher productivity when we control for selection effects in Table 4.2.

Investments in each individual type of training are also positively and significantly related with labour productivity, with informal training showing the strongest relationship. In the OLS model, a one percent increase in investment in informal training is related to a labour productivity increase of 0.27 percent (model 4 ). This reduces to 0.17 percent for non-formal training (model 3) and to 0.09 percent for formal training (model 2). Very similar magnitudes are obtained when selection is addressed, with effects of $0.26,0.18$ and 0.07 percent, respectively. However, these findings are obtained when each training type is included in the model individually. When combining all three simultaneously (model 5), only the significant conditional correlation between informal training investments and labour productivity remains. This lends support to the hypothesis made by some studies 
(Almeida and de Faria, 2014[84]; Dosi et al., 2019 [103]; Fialho, Quintini and Vandeweyer, $\left.2019_{[79]}\right)$ that returns to learning-by-doing and learning from peers and supervisors are substantial and, based on our estimates, even most important.

The result that all three types of investment in training are significant when the other training types are not included suggest that the different types of training are related to each other. This is also confirmed by observing similar scatter plots for the different investment in training variables with labour productivity in Figure 4.2, Figure 4.3 and the figures in Figure A.3. A strong correlation between the different training variables, which is observed in the correlation matrix in Table A.1, may lead to multicollinearity issues. This may explain why the positive and highly significant coefficients for formal and non-formal training turn insignificant when informal training is included. Our interpretation of the results is that both formal, non-formal and informal training are important for productivity, but that informal training is the most important one ${ }^{21}$. This result has important policy implications. Besides the importance of formal and non-formal training, allowing workers to learn from superiors and peers and to share information seem key to enhance productivity.

The role of training is also noteworthy in the selection model. Selection model (1a) shows that overall investment in training is seemingly negatively and significantly associated with the probability to innovate. By adding each type of training individually (model 2a, 3a and 4a) as well as all three combined (model 5a), we see that it is solely driven by the negative and significant relationship between investment in formal training and the probability to innovate. While this unexpected finding deserves more investigation, it may reflect a tradeoff between enrolment in formal education and the time available for innovative activity. Also, the negative relationship that emerges may stem from the fact that the workers (i.e. researchers and inventors) responsible for the generation of innovations are typically not the ones who enrol in formal education, because they already have high education levels.

Another set of variables, which are of interest in this paper, are cognitive and task-based skills. Here the findings are more mixed. While task-based STEM skills generally do not show any significant correlation with labour productivity, ICT as well as cognitive skills do, depending on the model specification.

The coefficient for ICT task-based skills is always positive and becomes statistically significant at the 10 percent level once we control for formal training only (model 2), informal training only (model 4) or all training types together (model 5) in Table 4.2 and once we control for informal training (model 4) in Table 4.3. In any case, a one-point increase in the mean ICT skill score is associated with a 0.01 percent increase in labour productivity.

It is further noteworthy that only ICT task-based skills, out of the skills we control for, are significantly and positively correlated with the innovation indicator in the selection model. Together with the findings observed in Table 4.2, these results suggest that ICT skills are also linked indirectly to labour productivity through their strong and positive correlation with innovative activities.

STEM-task based skills do not appear to play an important role in explaining labour productivity in our model specifications. This finding, which is at odds with findings in Cammeraat, Samek and Squicciarini $\left(2021_{[25]}\right)$, is further investigated in the sensitivity analysis.

Although cognitive skills (measured by median numeracy skill scores) generally do not show any significant relationship either, their dispersion, presented by the difference between the top 10 percentile and the median, has a positive and significant coefficient in the majority of labour productivity models. This suggests that within the top 50 percent of 
the cognitive skill distribution, the top 10 percent is more important than the median, confirming that highly skilled human capital is also important for the productivity of firms. This may contribute to explain a number of stylised facts proposed in existing literature such as skill premia as well as selection, self-selection and matching on the labour market.

The results for the selection model, presented in Table 4.3, show that our exclusion restriction, $R \& D$ expenditure, is significantly and positively associated with the probability of being an innovative industry. Nonetheless, finding an insignificant IMR in all labour productivity models, except for model $2 \mathrm{~b}$, indicates that the selection effect might not be a major problem after all, maybe because possible selection issues are already sufficiently absorbed by the cluster FE and other control variables.

\section{Table 4.2. Estimation results using OLS}

Conditional correlations between patents, skills, training and labour productivity

\begin{tabular}{|c|c|c|c|c|c|}
\hline & (1) & (2) & (3) & (4) & (5) \\
\hline \multirow[t]{2}{*}{ Log patents } & $0.055^{\star \star}$ & $0.062^{\star \star}$ & $0.059^{* *}$ & $0.038^{*}$ & $0.040^{*}$ \\
\hline & $(0.022)$ & $(0.022)$ & $(0.022)$ & $(0.022)$ & $(0.021)$ \\
\hline \multirow[t]{2}{*}{ Mean ICT skill score } & 0.008 & $0.012^{*}$ & 0.008 & $0.012^{*}$ & $0.011^{*}$ \\
\hline & $(0.007)$ & $(0.007)$ & $(0.007)$ & $(0.006)$ & $(0.006)$ \\
\hline \multirow[t]{2}{*}{ Mean STEM skill score } & -0.006 & -0.011 & -0.011 & -0.001 & 0.001 \\
\hline & $(0.007)$ & $(0.008)$ & $(0.008)$ & $(0.008)$ & $(0.007)$ \\
\hline \multirow[t]{2}{*}{ Median numeracy skill score } & 0.011 & 0.014 & 0.014 & 0.003 & 0.001 \\
\hline & $(0.023)$ & $(0.023)$ & $(0.026)$ & $(0.022)$ & $(0.021)$ \\
\hline \multirow[t]{2}{*}{ Difference between top 10 percentile and median numeracy skill score } & $0.045^{*}$ & $0.048^{\star *}$ & $0.049^{* *}$ & $0.042^{*}$ & $0.041^{*}$ \\
\hline & $(0.022)$ & $(0.021)$ & $(0.023)$ & $(0.021)$ & $(0.021)$ \\
\hline \multirow[t]{2}{*}{ Proportion of OC workers } & $0.004^{* \star *}$ & $0.004^{* *}$ & $0.005^{* * *}$ & $0.004^{* *}$ & $0.004^{* *}$ \\
\hline & $(0.001)$ & $(0.002)$ & $(0.002)$ & $(0.002)$ & $(0.002)$ \\
\hline \multirow[t]{2}{*}{ Log net fixed assets } & $0.375^{\star \star \star}$ & $0.379^{\star \star *}$ & $0.380^{* * *}$ & $0.382^{\star \star \star}$ & $0.370^{\star * *}$ \\
\hline & $(0.019)$ & $(0.018)$ & $(0.021)$ & $(0.018)$ & $(0.016)$ \\
\hline \multirow[t]{2}{*}{ Log training (total) } & $0.206^{* \star \star}$ & & & & \\
\hline & $(0.045)$ & & & & \\
\hline \multirow[t]{2}{*}{ Log formal training } & & $0.091^{* * *}$ & & & 0.001 \\
\hline & & $(0.025)$ & & & $(0.022)$ \\
\hline \multirow[t]{2}{*}{ Log non-formal training } & & & $0.169^{* \star *}$ & & 0.045 \\
\hline & & & $(0.042)$ & & $(0.051)$ \\
\hline \multirow[t]{2}{*}{ Log informal training } & & & & $0.271^{\star \star *}$ & $0.250^{\star \star *}$ \\
\hline & & & & $(0.044)$ & $(0.045)$ \\
\hline \multirow[t]{2}{*}{ Constant } & $9.574^{* \star *}$ & $12.030^{* * *}$ & $10.520^{\star \star \star}$ & $8.512^{\star \star \star}$ & $8.287^{* \star \star}$ \\
\hline & $(1.597)$ & $(1.387)$ & $(1.681)$ & $(1.118)$ & $(1.300)$ \\
\hline Observations & 263 & 263 & 276 & 276 & 263 \\
\hline R-squared & 0.83 & 0.82 & 0.83 & 0.85 & 0.85 \\
\hline Country cluster FE & YES & YES & YES & YES & YES \\
\hline Industry cluster FE & YES & YES & YES & YES & YES \\
\hline
\end{tabular}

Note: The country clusters include: 1) CAN, FRA, GBR, IRL and USA; 2) DNK, FIN, NOR and SWE; 3) AUT, BEL, CZE, DEU, EST, NLD and POL; 4) ITA and SVK; 5) JPN and KOR with cluster 1) being the reference group omitted from the regression. The industry clusters include: 1) agriculture, forestry and fishing (A) and mining and quarrying (B); 2) manufacturing (C); 3) utilities (D \& E) and construction (F); 4) information and communication (J) and financial and insurance activities $(\mathrm{K}) ; 5)$ public services $(\mathrm{O} \& \mathrm{P} \& \mathrm{Q})$ and 6) other business, social and personal services ( $G \& H \& I \& L \& M$ \& N \& R \& S) with 1) being the reference group. The full table including the country and industry cluster coefficients is presented in Table A.2. Robust standard errors are clustered at the country level. $*, * *$, and $* * *$ indicate that coefficients are significant at the $10 \%, 5 \%$ and $1 \%$ levels, respectively.

Source: Author's own compilation. 
Table 4.3. Estimation results addressing self-selection

Conditional correlations between patents, skills and labour productivity

\begin{tabular}{|c|c|c|c|c|c|c|c|c|c|c|}
\hline & $\begin{array}{l}\text { Selection } \\
\text { (1a) }\end{array}$ & $\begin{array}{l}\text { LP } \\
(1 b)\end{array}$ & $\begin{array}{l}\text { Selection } \\
\text { (2a) }\end{array}$ & $\begin{array}{l}\mathrm{LP} \\
(2 \mathrm{~b})\end{array}$ & $\begin{array}{l}\text { Selection } \\
\text { (3a) }\end{array}$ & $\begin{array}{l}\mathrm{LP} \\
(3 \mathrm{~b})\end{array}$ & $\begin{array}{l}\text { Selection } \\
\text { (4a) }\end{array}$ & $\begin{array}{l}\mathrm{LP} \\
(4 \mathrm{~b})\end{array}$ & $\begin{array}{l}\text { Selection } \\
\text { (5a) }\end{array}$ & $\begin{array}{l}\mathrm{LP} \\
(5 \mathrm{~b})\end{array}$ \\
\hline \multirow[t]{2}{*}{ Log R\&D } & $0.304^{* * *}$ & & $0.327^{\star \star *}$ & & $0.240^{\star * *}$ & & $0.228^{* \star *}$ & & $0.318^{\star \star \star}$ & \\
\hline & $(0.087)$ & & $(0.091)$ & & $(0.080)$ & & $(0.081)$ & & $(0.094)$ & \\
\hline \multirow[t]{2}{*}{ IMR } & & -0.054 & & $-0.075^{\star}$ & & -0.052 & & -0.054 & & -0.058 \\
\hline & & $(0.036)$ & & $(0.037)$ & & $(0.037)$ & & $(0.034)$ & & $(0.034)$ \\
\hline \multirow[t]{2}{*}{ Log patents } & & $0.056^{*}$ & & $0.067^{* *}$ & & $0.055^{\star}$ & & 0.046 & & 0.045 \\
\hline & & $(0.029)$ & & $(0.029)$ & & $(0.028)$ & & $(0.026)$ & & $(0.027)$ \\
\hline \multirow[t]{2}{*}{ Mean ICT skill } & $0.159^{* * *}$ & 0.006 & $0.165^{\star \star \star}$ & 0.009 & $0.125^{\star \star *}$ & 0.007 & $0.110^{* * *}$ & $0.011^{* *}$ & $0.164^{\star \star *}$ & 0.009 \\
\hline & $(0.045)$ & $(0.006)$ & $(0.046)$ & $(0.006)$ & $(0.039)$ & $(0.006)$ & $(0.037)$ & $(0.005)$ & $(0.046)$ & $(0.005)$ \\
\hline \multirow[t]{2}{*}{ Mean STEM skill } & 0.023 & -0.006 & 0.024 & -0.011 & 0.039 & -0.007 & 0.049 & 0.001 & 0.029 & -0.000 \\
\hline & $(0.035)$ & $(0.009)$ & $(0.035)$ & $(0.009)$ & $(0.033)$ & $(0.009)$ & $(0.035)$ & $(0.009)$ & $(0.037)$ & $(0.008)$ \\
\hline \multirow{2}{*}{$\begin{array}{l}\text { Median numeracy } \\
\text { skill }\end{array}$} & -0.082 & 0.026 & -0.073 & 0.031 & -0.088 & 0.020 & -0.093 & 0.004 & -0.079 & 0.015 \\
\hline & $(0.090)$ & $(0.021)$ & $(0.093)$ & $(0.021)$ & $(0.084)$ & $(0.020)$ & $(0.084)$ & $(0.018)$ & $(0.094)$ & $(0.021)$ \\
\hline \multirow{2}{*}{$\begin{array}{l}\text { Dif. between top } 10 \\
\text { perc. \& median } \\
\text { numeracy skill }\end{array}$} & 0.025 & 0.038 & 0.058 & $0.045^{*}$ & 0.037 & $0.044^{*}$ & 0.022 & 0.031 & 0.053 & 0.031 \\
\hline & $(0.117)$ & $(0.023)$ & $(0.122)$ & $(0.022)$ & $(0.108)$ & $(0.024)$ & $(0.109)$ & $(0.024)$ & $(0.123)$ & $(0.023)$ \\
\hline \multirow[t]{2}{*}{ Prop. OC workers } & 0.001 & $0.003^{*}$ & 0.003 & $0.003^{*}$ & 0.001 & $0.004^{* *}$ & 0.002 & $0.003^{*}$ & 0.003 & 0.003 \\
\hline & $(0.010)$ & $(0.002)$ & $(0.010)$ & $(0.002)$ & $(0.010)$ & $(0.002)$ & $(0.009)$ & $(0.002)$ & $(0.010)$ & $(0.002)$ \\
\hline \multirow[t]{2}{*}{ Log net fixed ass. } & -0.044 & $0.378^{* * *}$ & -0.081 & $0.387^{\star * *}$ & -0.019 & $0.374^{* * *}$ & -0.038 & $0.381^{* \star *}$ & -0.084 & $0.374^{* * *}$ \\
\hline & $(0.107)$ & $(0.026)$ & $(0.109)$ & $(0.024)$ & $(0.103)$ & $(0.024)$ & $(0.103)$ & $(0.019)$ & $(0.111)$ & $(0.022)$ \\
\hline \multirow[t]{2}{*}{ Log training (total) } & $-0.767^{* * *}$ & $0.190^{* * *}$ & & & & & & & & \\
\hline & $(0.264)$ & $(0.055)$ & & & & & & & & \\
\hline \multirow[t]{2}{*}{ Log formal training } & & & $-0.590^{\star \star *}$ & $0.072^{\star * *}$ & & & & & $-0.596^{\star \star \star}$ & -0.000 \\
\hline & & & $(0.165)$ & $(0.024)$ & & & & & $(0.184)$ & $(0.024)$ \\
\hline \multirow[t]{2}{*}{ Log non-formal t. } & & & & & -0.344 & $0.179^{\star \star \star}$ & & & -0.032 & 0.066 \\
\hline & & & & & $(0.221)$ & $(0.053)$ & & & $(0.306)$ & $(0.055)$ \\
\hline \multirow[t]{2}{*}{ Log informal t. } & & & & & & & -0.045 & $0.264^{\star * \star}$ & 0.130 & $0.217^{\star \star \star}$ \\
\hline & & & & & & & $(0.268)$ & $(0.045)$ & $(0.351)$ & $(0.050)$ \\
\hline \multirow[t]{2}{*}{ Constant } & $9.204^{* * *}$ & $15.980^{* * *}$ & 7.694 & $11.070^{* * *}$ & 2.742 & $9.631^{* * *}$ & -2.610 & $8.342^{* * *}$ & 6.096 & $7.653^{\star * *}$ \\
\hline & $(2.287)$ & $(1.424)$ & (6.001) & $(1.440)$ & $(6.368)$ & $(1.579)$ & (6.697) & $(1.317)$ & (7.801) & (1.641) \\
\hline Observations & \multicolumn{2}{|c|}{222} & \multicolumn{2}{|c|}{222} & \multicolumn{2}{|c|}{232} & \multicolumn{2}{|c|}{232} & \multicolumn{2}{|c|}{222} \\
\hline R-squared & \multicolumn{2}{|c|}{0.83} & \multicolumn{2}{|c|}{0.82} & \multicolumn{2}{|c|}{0.84} & \multicolumn{2}{|c|}{0.85} & \multicolumn{2}{|c|}{0.84} \\
\hline Country cluster FE & YES & YES & YES & YES & YES & YES & YES & YES & YES & YES \\
\hline Industry cluster FE & YES & YES & YES & YES & YES & YES & YES & YES & YES & YES \\
\hline
\end{tabular}

Note: The country clusters include: 1) CAN, FRA, GBR, IRL and USA; 2) DNK, FIN, NOR and SWE; 3) AUT, BEL, CZE, DEU, EST, NLD and POL; 4) ITA and SVK; 5) JPN and KOR with cluster 1) being the reference group omitted from the regression. The industry clusters include: 1) agriculture, forestry and fishing (A) and mining and quarrying (B); 2) manufacturing (C); 3) utilities (D \& E) and construction (F); 4) information and communication $(\mathrm{J})$ and financial and insurance activities $(\mathrm{K})$; 5) public services $(\mathrm{O} \& \mathrm{P} \& \mathrm{Q})$ and 6) other business, social and personal services ( $G \& H \& I \& L \& M \& N \& R \& S$ ) with 1 ) being the reference group. The full table including the country and industry cluster coefficients is presented in Table A.3. Robust standard errors are clustered at the country level. *, **, and *** indicate that coefficients are significant at the $10 \%, 5 \%$ and $1 \%$ levels, respectively.

Source: Author's own compilation.

Finally, Table A. 2 and Table A. 3 show the full results of Table 4.2 and Table 4.3, including the country and industry cluster coefficients. Figure 4.4 shows the industry coefficients in a bar chart, to facilitate comparison between different industries. Compared to agriculture and mining, which is used as the reference group, the largest coefficient is found for the 
manufacturing cluster and the lowest coefficient for the public sector. This suggests that, after controlling for our variables of interest and country cluster FE, manufacturing industries are the most productive and public services are the least productive industries. One caveat, however, is that productivity in the public sector is hard to valuate.

\section{Figure 4.4. Industry clusters' coefficients}

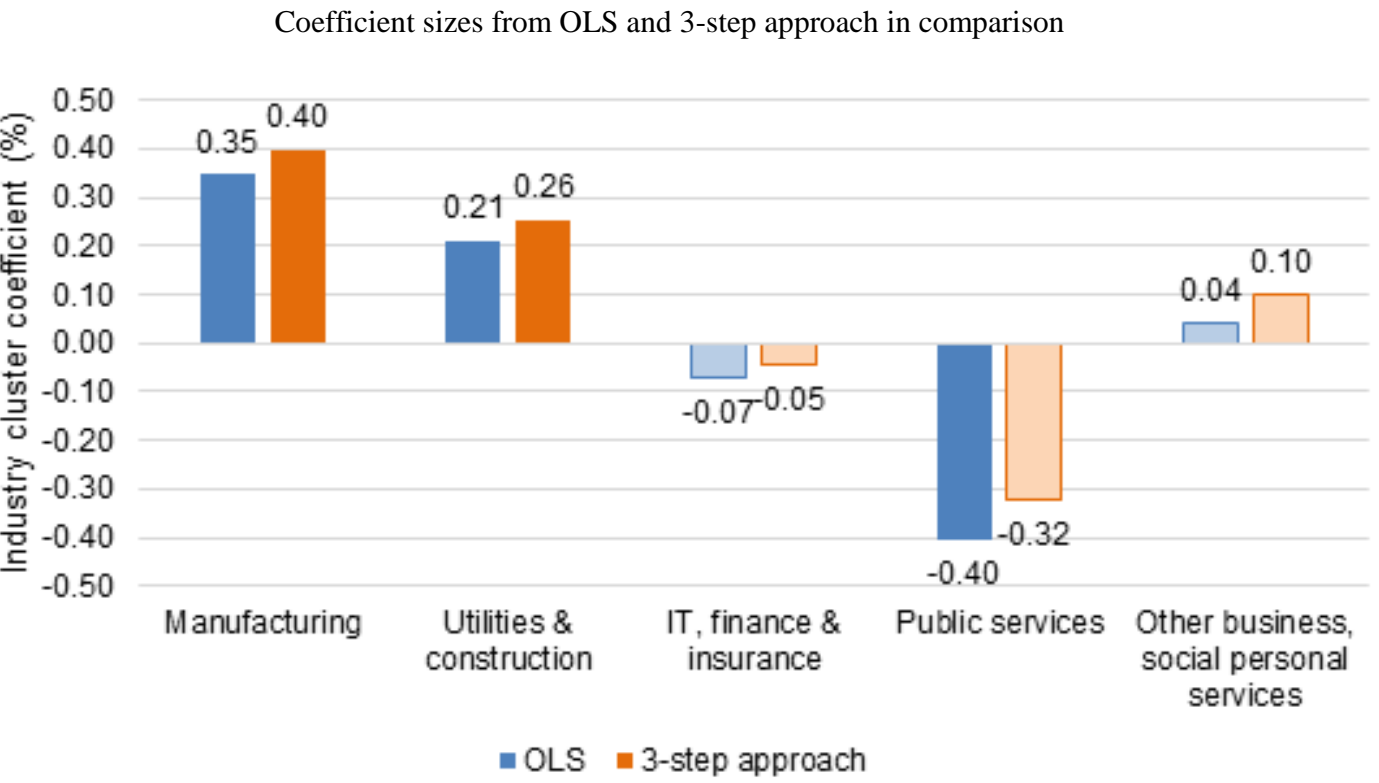

Note: Figures are based on regression results presented in Table A.2 (OLS) and Table A.3 (3-step approach). Agriculture and mining are used as the reference industry cluster. The darker coloured bars present coefficients significant at least at the $10 \%$ level, while the paler shaded bars show insignificant coefficients.

Source: Author's own compilation

Overall, Table 4.3 confirms our OLS results in Table 4.2, pointing out the importance of innovation, investment in training, OC and physical capital intensity for productivity. Table 4.3 also provides some further evidence about the importance of ICT skills for productivity through innovation.

When we explore different measures of labour productivity and replace our measure of value added per employee with value added per hour worked, our results remain robust. However, the positive coefficient for ICT skills becomes significantly related to labour productivity in all model specifications, suggesting that workers with high ICT skills produce on average more output per hour worked. These results are available from the authors upon request.

\subsection{Sensitivity Analysis - What is the Role of STEM Skills for Productivity?}

We here assess the robustness of the results controlling for different combinations of country (cluster) and industry (cluster) FE. These results, presented in Table 4.4, provide further evidence for the importance of controlling for country and industry cluster FE, as we did in the models presented in the previous section.

In addition, this section provides insights about how results change depending on studying differences between industries or differences between countries, by controlling for country FE or industry FE, respectively. Finally, we further investigate here the relationship between STEM skills and productivity (Table 4.2 and Table 4.3), because it is at odds with 
existing studies and with results in (Cammeraat, Samek and Squicciarini, 2021 [25]) where we use (almost) the same data.

The first column of Table 4.4 does not include any FE. The second and third columns control for unobserved individual country and individual industry FE, respectively. Column (5) presents the results using only the country cluster FE and column (6) the results using only industry cluster FE. Finally, column (7), our preferred model - which we also used in Table 4.2 and Table 4.3 - controls for both country and industry cluster FE.

Irrespective of the specification, most results are similar with respect to the sign and significance level of the coefficients presented in Table 4.2 and Table 4.3. Patents and physical capital intensity are again positively and significantly related to productivity in all different model specifications. Also investment in training is positively and significantly related to productivity in all models except for column 2.

More pronounced differences across the different FE models emerge for some of the skill variables. For ICT skills, we no longer find a statistically significant coefficient in Table 4.4, but the coefficient is mostly positive and larger when controlled for differences in industry characteristics in columns 3,6 and 7 .

In contrast, STEM skills relate positively and significantly to productivity now when controlling for country FE (column 2) or both country and industry FE (column 4). Finding a positive relationship when differences across countries are controlled for suggests that STEM skills are important for the productivity of industries, stressing the importance of industrial policy. In our individual country and industry FE model, column 4, a one-point increase in the average STEM skill score relates to a 0.2 percent increase in productivity, suggesting that a standard deviation increase in STEM skill scores relates to a 1.1 percent increase in labour productivity. However, we do not find this result when no FE are used (column 1), only industry FE are used (column 3), nor in our preferred model where individual country and industry fixed effects are replaced by cluster FE (to free up more degrees of freedom, column 5). We therefore conclude that there is some evidence for a positive relationship between STEM and productivity in this paper, but that it depends on the type of comparison made.

For the median numeracy skill score, we also find positive but insignificant coefficients in all columns, except for column 2 , in which we find a negative and statistically significant coefficient when we only include country FE. A possible explanation for the negative coefficient for numeracy in model 2 is that the positive effect of numeracy is already absorbed by our task-based STEM variable, since the coefficient for STEM is much larger compared to the other columns. Task-based STEM skills could be interpreted as a proxy for relatively advanced numeracy skills used on the job. Finding a negative coefficient for numeracy when controlling for task-based STEM scores could therefore be interpreted as suggestive evidence for a mismatch of skills between industries. However, a more likely explanation may be that including only country FE, absorbing all variation between countries, while leaving less degrees of freedom for the other variables, may be too restrictive, given the positive coefficient observed in all other FE models.

The skill dispersion variable for numeracy, presented by the difference between the top 10 percentile and the median, has a positive and significant coefficient in almost all columns. This suggests a robust positive relationship between dispersion in cognitive skills and productivity.

Finally, more mixed findings emerge in relation to the proportion of OC workers. This suggest caution when interpreting the results in Table 4.2 and Table 4.3 
Table 4.4. Estimation results with different fixed effects

Conditional correlations between patents, skills and labour productivity

\begin{tabular}{|c|c|c|c|c|c|c|c|}
\hline & (1) & (2) & (3) & (4) & (5) & (6) & (7) \\
\hline \multirow[t]{2}{*}{ Log patents } & $0.129^{* \star *}$ & $0.089^{* * *}$ & $0.047^{*}$ & $0.028^{*}$ & $0.129^{* \star *}$ & $0.053^{* \star}$ & $0.055^{\star \star}$ \\
\hline & $(0.018)$ & $(0.016)$ & $(0.026)$ & $(0.016)$ & $(0.017)$ & $(0.022)$ & $(0.022)$ \\
\hline \multirow[t]{2}{*}{ Mean ICT skill score } & -0.002 & 0.002 & 0.005 & 0.003 & -0.003 & 0.010 & 0.008 \\
\hline & $(0.007)$ & $(0.005)$ & $(0.009)$ & $(0.006)$ & $(0.005)$ & $(0.007)$ & $(0.007)$ \\
\hline \multirow{2}{*}{ Mean STEM skill score } & 0.007 & $0.050^{* * *}$ & $-0.018^{* *}$ & $0.018^{* *}$ & 0.005 & -0.005 & -0.006 \\
\hline & $(0.007)$ & $(0.008)$ & $(0.006)$ & $(0.007)$ & $(0.006)$ & $(0.008)$ & $(0.007)$ \\
\hline \multirow[t]{2}{*}{ Median numeracy skill score } & 0.002 & $-0.052^{* *}$ & 0.017 & 0.009 & 0.014 & -0.004 & 0.011 \\
\hline & $(0.023)$ & $(0.020)$ & $(0.020)$ & $(0.015)$ & $(0.023)$ & $(0.018)$ & $(0.023)$ \\
\hline \multirow{2}{*}{$\begin{array}{l}\text { Difference between top } 10 \text { percentile and median numeracy } \\
\text { skill score }\end{array}$} & $0.068^{* \star}$ & -0.008 & $0.066^{* * *}$ & 0.013 & $0.054^{* *}$ & $0.052^{* *}$ & $0.045^{*}$ \\
\hline & $(0.031)$ & $(0.024)$ & $(0.021)$ & $(0.015)$ & $(0.025)$ & $(0.024)$ & $(0.022)$ \\
\hline \multirow[t]{2}{*}{ Proportion of OC workers } & 0.000 & $-0.004^{* *}$ & $0.004^{*}$ & 0.000 & -0.001 & $0.005^{\star \star}$ & $0.004^{\star \star \star}$ \\
\hline & $(0.002)$ & $(0.002)$ & $(0.002)$ & $(0.002)$ & $(0.002)$ & $(0.002)$ & $(0.001)$ \\
\hline \multirow[t]{2}{*}{ Log net fixed assets } & $0.367^{\star \star \star}$ & $0.346^{\star \star *}$ & $0.275^{\star \star \star}$ & $0.221^{* * *}$ & $0.367^{\star \star \star}$ & $0.374^{\star \star *}$ & $0.375^{\star \star *}$ \\
\hline & $(0.022)$ & $(0.018)$ & $(0.058)$ & $(0.037)$ & $(0.020)$ & $(0.020)$ & $(0.019)$ \\
\hline \multirow[t]{2}{*}{ Log training investment } & $0.224^{* * *}$ & -0.017 & $0.266^{* \star *}$ & $0.113^{*}$ & $0.194^{* * *}$ & $0.229^{* * *}$ & $0.206^{* * *}$ \\
\hline & $(0.053)$ & $(0.045)$ & $(0.050)$ & $(0.055)$ & $(0.046)$ & $(0.049)$ & $(0.045)$ \\
\hline \multirow[t]{2}{*}{ Constant } & $9.204^{\star * *}$ & $15.980^{* * *}$ & $10.820^{* * *}$ & $15.620^{\star * *}$ & $9.582^{\star * *}$ & $9.589^{\star \star *}$ & $9.574^{* * *}$ \\
\hline & $(2.287)$ & $(1.424)$ & $(1.856)$ & $(1.539)$ & $(1.563)$ & $(1.665)$ & $(1.597)$ \\
\hline Observations & 263 & 263 & 263 & 263 & 263 & 263 & 263 \\
\hline R-squared & 0.77 & 0.86 & 0.88 & 0.94 & 0.78 & 0.82 & 0.83 \\
\hline Country FE & NO & YES & NO & YES & NO & NO & NO \\
\hline Country cluster FE & NO & NO & NO & NO & YES & NO & YES \\
\hline Industry FE & NO & NO & YES & YES & NO & NO & NO \\
\hline Industry cluster FE & NO & NO & NO & NO & NO & YES & YES \\
\hline
\end{tabular}

Note: The country clusters include: 1) CAN, FRA, GBR, IRL and USA; 2) DNK, FIN, NOR and SWE; 3) AUT, BEL, CZE, DEU, EST, NLD and POL; 4) ITA and SVK; 5) JPN and KOR with cluster 1) being the reference group omitted from the regression. The industry clusters include: 1) agriculture, forestry and fishing (A) and mining and quarrying (B); 2) manufacturing (C); 3) utilities (D \& E) and construction (F); 4) information and communication $(\mathrm{J})$ and financial and insurance activities $(\mathrm{K})$; 5) public services $(\mathrm{O} \& \mathrm{P} \& \mathrm{Q})$ and 6) other business, social and personal services ( $G \& H \& I \& L \& M \& N \& R \& S$ ) with 1 ) being the reference group. The full table including the country and industry cluster coefficients is presented in Table A.4 . Robust standard errors are clustered at the country level. *,**, and *** indicate that coefficients are significant at the $10 \%, 5 \%$ and $1 \%$ levels, respectively.

Source: Author's own compilation. 


\section{Chapter 5. Conclusion}

Although a lot of research, especially in recent years, has examined the link between innovation and productivity, only little evidence exists on the role played by human capital in this relationship. This paper contributes to existing work by exploring the role of skills as well as investments in different types of training for economic performance, as both are key in translating R\&D into innovative output and efficiency gains.

In order to study these relationships, a dataset was constructed relying on a wide array of sources. The results thus obtained show that productivity increases significantly with innovative output (measured by our patent indicator), investment in training, the proportion of OC workers and physical capital intensity (measured by net fixed assets). A one percent increase in patents relates to 0.04-0.06 percent higher productivity while this effect increases to $0.19-0.21$ percent higher productivity with every one percent increase in investments in total training. A one-percentage point increase in the proportion of OC workers relates to $0.003-0.005$ percent higher productivity while a one percent increase in net fixed assets is related to a $0.37-0.39$ percent increase in productivity. These findings are consistent regardless of whether potential selection issues are addressed or not.

When investment in training as a whole is disentangled and investment in formal, informal as well as non-formal training are explored individually, the biggest productivity gain is observed for informal training. A one percent increase in investment in informal training is associated with $0.26-0.27$ percent increase in productivity. This reduces to $0.17-0.18$ percent for non-formal training and to 0.07-0.09 percent for formal training, but remains highly significant. However, when combining all three types simultaneously, only the significance of informal training investment remains ${ }^{22}$, lending support to the hypotheses made by existing studies that returns to learning-by-doing and learning from peers and supervisors are substantial and deserve further attention.

Besides the importance of formal and non-formal training, more priority should therefore be given to informal training. An internal learning culture fostered by non-formal training and by organisations that promote autonomy, teamwork, team psychological safety ${ }^{23}$, job satisfaction, activities for reflection and challenging experiences may go a long way (Edmondson, 1999 ${ }_{[104]}$; Enos, Kehrhahn and Bell, 2003 ${ }_{[105]}$; Rowden and Conine, $2005_{[106]}$; Fialho, Quintini and Vandeweyer, 2019 $\left.{ }_{[79]}\right)$. Concrete examples of possible ways to foster the development of learning organisations could be (peer) mentorship programs, performance and development interviews, peer reviews and apprenticeships.

The findings on the role of skills are slightly more nuanced. While median cognitive skills are not associated with productivity, their dispersion appears to do so in the majority of models, suggesting that within the top 50 percent of the cognitive skill distribution, the top 10 percent is more important than the median. This confirms that highly skilled human capital is also important for the productivity of firms. This may contribute to explain a number of stylised facts proposed in existing literature such as skill premia as well as selection, self-selection and matching on the labour market.

Also, while STEM skills generally do not show any significant correlation with labour productivity, ICT as well as cognitive skills do so in part. In the presence of significant coefficients, a one standard deviation increase in the mean ICT skill score is associated with a 0.1 percent increase in labour productivity. It further appears that ICT skills are also linked indirectly to labour productivity, through their strong and positive correlation with innovative activities. STEM skills are indeed important for productivity when differences 
between individual countries are controlled for, with a one-point increase in the average STEM score that relates to a 0.2 percent increase in productivity. Since this finding is not robust when no FE or when cluster FE are used, this study can only provide limited evidence about the relationship between STEM skills and productivity.

Overall our results call for the need to upgrade ICT task-based skills to facilitate innovative activities and improve productivity. Moreover, they emphasise the need to know more about the role of training policies in upgrading skills and supporting innovative activities, with the aim to improve productivity, either directly or indirectly. Moreover, they clearly highlight the importance of informal training, suggesting that it is crucial for policy makers to engage with and encourage firms to evolve into learning organisations, as these are the most productive ones. Fostering investment in information and communication sharing and endowing workers with the necessary socio-emotional skills (in addition to the relevant technical or speciality ones) needed to work in teams, communicate and learning how to learn becomes a must for economic performance. 


\section{Endnotes}

1 STEM is the acronym corresponding to Science, Technology, Engineering, and Mathematics. The OECD Skills Outlook (OECD, 2017 $[14]$ ) refers to task based skills as those skills that relate to the performance of business tasks at work. The full locution used in the case of STEM skills in Grundke et al. (2017 $\left.7_{[7]}\right)$ is "STEM - quantitative skills". STEM-quantitative task based skills relate to the performance of numeric tasks such as 'Use simple algebra or formulas' or 'Use advanced math or statistics', as captured in the OECD Survey of Adult Skills and are broadly interpreted as skills necessary for Science, Technology, Engineering and Mathematics.

${ }^{2}$ An exception for STEM is presented in the sensitivity analysis, which is only positively and significantly related to productivity when individual country and industry fixed effects are controlled for.

${ }^{3}$ It has become common in this literature to implement such type of models, to try to address endogeneity and selectivity.

${ }^{4}$ This is not surprising given that these types of training are usually not mutually exclusive and are heterogeneous across firms and occupations, in addition to being difficult to measure (Bassanini et al., 2005[49]).

${ }^{5}$ This result may be surprising, as the opposite holds true in the case of the impact of firmsponsored training on productivity: classroom training is typically found to have a much larger impact on productivity than does on-the-job training.

${ }^{6}$ It has an abundance of definitions but has the common theme that knowledge improves actions and emphasises the interaction between the organisation and its environment (McDougall and Beattie, 1998 ${ }_{[107]}$ ).

${ }^{7}$ For example, Leuven and Oosterbek $\left(2004_{[108]} ; 2008_{[109]}\right)$ argue that they may be finding low or no effects of training because they are using individual wages as opposed to firm productivity.

${ }^{8}$ Due to a relatively small sample size, we rely on clustered rather than individual FE to reduce the number of variables in the model and reduce the risk of overfitting the model.

${ }^{9} \mathrm{We}$ are aware that not all innovation is patented and that firms differ in their propensity to patent.

${ }^{10}$ The number of patents at the country-industry level are ordered and the highest and lowest 1 percentile of values are replaced by the next value counting inwards from the extremes.

${ }^{11}$ Since the two numeracy variables already capture base skills, the educational attainment variable is dropped from the equation to avoid multicollinearity problems and to include observations for the countries for which we do not have industry-level data on educational attainment.

12 Although problem solving skills, which are also measured in PIAAC, are arguably relevant for the development of patents and the enhancement of labour productivity, they are not used either, because they relate to technology rich environments, and therefore represent a subset of more general problem solving skills. More importantly, Italy, France and Spain did not make this assessment and would thus need to be left aside of the analysis, in case. Moreover, problem-solving is correlated with both STEM and numeracy already, 
having all these overlapping skills in the model together may lead to multicollinearity problems and thereby bias regression results.

${ }^{13}$ This threshold is constructed across industries but by country and hence the indicator is country specific.

${ }^{14}$ Controlling for firm size in both the selection model and the productivity model does not impact the results. Given the very small insignificant coefficient, we decided to drop it again from our model specifications. Finding no effect of firm size provides some evidence that our models sufficiently capture the selection effect, at least to the extent firm size and innovation go together.

${ }^{15}$ Public services (O\&P\&Q) are located in the bottom left part of the graph, but economic output in the public sector is hard to measure.

${ }^{16}$ The equivalent graph depicting formal and non-formal training is presented in Figure A.3

${ }^{17}$ Given that it increases with investment in all types of training, as shown in Figure 4.2

${ }^{18}$ CAN, FRA, GBR, IRL and USA; DNK, FIN, NOR and SWE; AUT, BEL, CZE, DEU, EST, NLD and POL; ITA and SVK; JPN and KOR.

${ }^{19}$ Agriculture, forestry and fishing (A) and mining and quarrying (B); manufacturing (C); utilities (D \& E) and construction (F); information and communication (J) and financial and insurance activities $(\mathrm{K})$; public services $(\mathrm{O} \& \mathrm{P} \& \mathrm{Q})$; other business, social and personal services ( $G$ \& H \& I \& L \& M \& N \& R \& S).

${ }^{20}$ Ideally, we would also like to include both country and industry individual fixed effects to our different model specifications, but this would add a large number of country and industry control dummy variables, using many degrees of freedom. This would lead, in combination with our small sample size (260 observations), to overfitting problems. We nevertheless show some results using different combinations of country and industry (cluster) fixed effects in Table 4.4 in the sensitivity analysis.

${ }^{21}$ A second interpretation is that there may be important spillovers and that formal and nonformal training may only increase productivity if there is enough informal training to put the learned lessons into practice.

${ }^{22}$ However, given that the different training variables are highly related to each other, multicollinearity issues are likely to occur when all included simultaneously. Our interpretation of the results is therefore that formal, non-formal and informal training are all important, given their high level of significance when included separately, but informal training is most important.

${ }^{23}$ Team psychological safety is a shared belief held by members of a team that the team is safe for interpersonal risk taking (Edmondson, 1999 $9_{[104]}$ ). 


\section{References}

Acemoglu, D. and J. Pischke (1999), "The Structure of Wages and Investment in General Training”, Journal of Political Economy, Vol. 107/3, pp. 539-572, http://dx.doi.org/10.1086/250071.

Almeida, R. and R. Aterido (2010), "Investment in job training : why are SMES lagging so much behind ? (English).”, Policy Research working paper, Vol. no. WPS 5358.

Almeida, R. and P. Carneiro (2009), "The return to firm investments in human capital”, Labour Economics, Vol. 16/1, pp. 97-106, http://dx.doi.org/10.1016/j.labeco.2008.06.002.

Almeida, R. and M. de Faria (2014), "The Wage Returns to On-the-Job Training: Evidence from Matched Employer-Employee Data”, IZA Discussion Paper, Vol. No. 8314.

Ang, J. and J. Madsen (2014), "Imitation versus innovation in an aging society: international evidence since 1870”, Journal of Population Economics, Vol. 28/2, pp. 299-327, http://dx.doi.org/10.1007/s00148-014-0513-0.

Arulampalam, W., A. Booth and M. Bryan (2004), "Training in Europe", Journal of the European Economic Association, Vol. 2/2-3, pp. 346-360, http://dx.doi.org/10.1162/154247604323068041.

Arulampalam, W., A. Booth and P. Elias (1995), "Work-Related Training And Earnings Growth For Young Men In Britain", University of Warwick, Department of Economics, Vol. Economic Research Papers 268689.

Ashton, D. (2008), Challenging the Myths about Learning and Training in Small and Medium-Sized Enterprises: Implications for Public Policy, ILO.

Baldwin, T. and J. Ford (1988), "Transfer of Training: A Review and Directions for Future Research", Personnel Psychology, Vol. 41/1, pp. 63-105, http://dx.doi.org/10.1111/j.17446570.1988.tb00632.x.

Barrett, A. and P. O’Connell (2001), “Does Training Generally Work? The Returns to In-Company Training”, Industrial and Labor Relations Review, Vol. 54/3, p. 647, http://dx.doi.org/10.2307/2695995.

Barron, J., D. Black and M. Loewenstein (1989), “Job Matching and On-the-Job Training”, Journal of Labor Economics, Vol. 7/1, pp. 1-19, http://dx.doi.org/10.1086/298196.

Bartel, A. (2000), “Measuring the Employer's Return on Investments in Training: Evidence from the Literature", Industrial Relations: A Journal of Economy and Society, Vol. 39/3, pp. 502-524, http://dx.doi.org/10.1111/0019-8676.00178.

Bartel, A. (1995), "Training, Wage Growth, and Job Performance: Evidence from a Company Database", Journal of Labor Economics, Vol. 13/3, pp. 401-425, http://dx.doi.org/10.1086/298380.

Bartel, A. (1994), "Productivity Gains from the Implementation of Employee Training Programs", Industrial Relations, Vol. 33/4, pp. 411-425, http://dx.doi.org/10.1111/j.1468-232x.1994.tb00349.x. 
Bassanini, A. et al. (2005), "Workplace Training in Europe”, IZA Discussion Paper No. 1640.

Bauernschuster, S., O. Falck and S. Heblich (2009), “Training and Innovation”, Journal of Human Capital, Vol. 3/4, pp. 323-353, http://dx.doi.org/10.1086/653713.

Bechichi, N. et al. (2018), "Moving between jobs: An analysis of occupation distances and skill needs", OECD Science, Technology and Industry Policy Papers, No. 52, OECD Publishing, Paris, https://dx.doi.org/10.1787/d35017ee-en.

Bell, D. (1976), "The Coming of the Post-Industrial Society", The Educational Forum, Vol. 40/4, pp. 574-579, http://dx.doi.org/10.1080/00131727609336501.

Bishop, D. (2017), “Context, agency and professional workplace learning: Trainee accountants in large and small practices", Education and Training, Vol. 59/5, pp. 516-533.

Bishop, D. (2012), "Firm size and skill formation processes: an emerging debate", Journal of Education and Work, Vol. 25/5, pp. 507-521, http://dx.doi.org/10.1080/13639080.2012.661848.

Black, S. and L. Lynch (1996), "Human-Capital Investments and Productivity", The American Economic Review, Vol. 86/2, pp. 263-267.

Bloom, N., R. Sadun and J. Van Reenen (2012), "The Organization of Firms Across Countries*", The Quarterly Journal of Economics, Vol. 127/4, pp. 1663-1705, http://dx.doi.org/10.1093/qje/qje029.

Bloom, N. and J. Van Reenen (2010), "Why Do Management Practices Differ across Firms and Countries?", Journal of Economic Perspectives, Vol. 24/1, pp. 203-224, http://dx.doi.org/10.1257/jep.24.1.203.

Blundell, R. et al. (2005), "Human Capital Investment: The Returns from Education and Training to the Individual, the Firm and the Economy”, Fiscal Studies, Vol. 20/1, pp. 1-23, http://dx.doi.org/10.1111/j.1475-5890.1999.tb00001.x.

Bolli, T., U. Renold and M. Wörter (2017), "Vertical educational diversity and innovation performance", Economics of Innovation and New Technology, Vol. 27/2, pp. 107-131, http://dx.doi.org/10.1080/10438599.2017.1314075.

Boothby, D., A. Dufour and J. Tang (2010), “Technology adoption, training and productivity performance", Research Policy, Vol. 39/5, pp. 650-661, http://dx.doi.org/10.1016/j.respol.2010.02.011.

Braconier, H., G. Nicoletti and B. Westmore (2014), "Policy Challenges for the Next 50 Years", OECD Economic Policy Papers, No. 9, OECD Publishing, Paris, https://dx.doi.org/10.1787/5jz18gs5fckfen.

Cammeraat, E., L. Samek and M. Squicciarini (2021), "Management, Skills and Productivity", $O E C D$ Science, Technology and Industry Policy Papers, Vol. OECD Publishing, Paris.

Campbell, M. (2006), "Counting the value of learning", Development and Learning in Organizations: An International Journal, Vol. 20/6, http://dx.doi.org/10.1108/dlo.2006.08120fad.002.

CEDEFOP (2014), "Macroeconomic benefits of vocational education and training", Research Paper No. 40, CEDEFOP (European Centre for the Development of Vocational Training)., http://dx.doi.org/10.2801/54994. 
Cohen, W. and D. Levinthal (1990), “Absorptive Capacity: A New Perspective on Learning and Innovation”, Administrative Science Quarterly, Vol. 35/1, p. 128, http://dx.doi.org/10.2307/2393553.

Cohen, W. and D. Levinthal (1989), "Innovation and Learning: The Two Faces of R \& D”, The Economic Journal, Vol. 99/397, p. 569, http://dx.doi.org/10.2307/2233763.

Colombo, E. and L. Stanca (2014), "The impact of training on productivity: evidence from a panel of Italian firms", International Journal of Manpower, Vol. 35/8, pp. 1140-1158, http://dx.doi.org/10.1108/ijm-08-2012-0121.

Conti, G. (2005), “Training, productivity and wages in Italy”, Labour Economics, Vol. 12/4, pp. 557576, http://dx.doi.org/10.1016/j.labeco.2005.05.007.

Corrado, C. et al. (2012), "Intangible Capital and Growth in Advanced Economies: Measurement Methods and Comparative Results", IZA Discussion Paper, Vol. No. 6733.

Corrado, C., C. Hulten and D. Sichel (2005), "Measuring capital and technology: an expanded framework", Measuring capital in the new economy, pp. 11-45, University of Chicago Press.

Crépon, B., E. Duguet and J. Mairesse (1998), "Research, Innovation And Productivi[Ty: An Econometric Analysis At The Firm Level”, Economics of Innovation and New Technology, Vol. 7/2, pp. 115-158, http://dx.doi.org/10.1080/10438599800000031.

Criscuolo, C. (2009), "Innovation and Productivity: Estimating the Core Model Across 18 Countries", in Innovation in Firms: A Microeconomic Perspective, OECD Publishing, Paris, https://dx.doi.org/10.1787/9789264056213-5-en.

Culpepper, P. and D. Finegold (eds.) (1999), The German Apprenticeship System under Strain, Berghahn Books.

Cunningham, L. and C. Rowley (2010), "Small and medium-sized enterprises in China: a literature review, human resource management and suggestions for further research", Asia Pacific Business Review, Vol. 16/3, pp. 319-337, http://dx.doi.org/10.1080/13602380903115948.

De Grip, A. and J. Sauermann (2012), "The Effects of Training on Own and Co-worker Productivity: Evidence from a Field Experiment”, The Economic Journal, Vol. 122/560, pp. 376-399, http://dx.doi.org/10.1111/j.1468-0297.2012.02500.x.

De la Fuente, A. and A. Ciccone (2003), "Human capital in a global and knowledge-based economy", Office for Official Publications of the European Communities, Vol. 562.

Dearden, L., H. Reed and J. Van Reenen (2006), “The Impact of Training on Productivity and Wages: Evidence from British Panel Data*”, Oxford Bulletin of Economics and Statistics, Vol. 68/4, pp. 397-421, http://dx.doi.org/10.1111/j.1468-0084.2006.00170.x.

Destré, G., L. Lévy-Garboua and M. Sollogoub (2008), "Learning from experience or learning from others?”, The Journal of Socio-Economics, Vol. 37/3, pp. 919-938, http://dx.doi.org/10.1016/j.socec.2006.12.085.

Diebolt, C. and R. Hippe (2018), "The long-run impact of human capital on innovation and economic development in the regions of Europe", Applied Economics, Vol. 51/5, pp. 542-563, http://dx.doi.org/10.1080/00036846.2018.1495820. 
Dosi, G. et al. (2019), "Neodualism in the Italian business firms: training, organizational capabilities, and productivity distributions", Small Business Economics, http://dx.doi.org/10.1007/s11187-01900295-x.

Dostie, B. (2017), “The Impact of Training on Innovation”, ILR Review, Vol. 71/1, pp. 64-87, http://dx.doi.org/10.1177/0019793917701116.

Dostie, B. (2013), "Estimating the Returns to Firm-Sponsored On-the-Job and Classroom Training", Journal of Human Capital, Vol. 7/2, pp. 161-189, http://dx.doi.org/10.1086/671186.

Edmondson, A. (1999), "Psychological Safety and Learning Behavior in Work Teams", Administrative Science Quarterly, Vol. 44/2, p. 350, http://dx.doi.org/10.2307/2666999.

Enos, M., M. Kehrhahn and A. Bell (2003), "Informal learning and the transfer of learning: How managers develop proficiency", Human Resource Development Quarterly, Vol. 14/4, pp. 369-387, http://dx.doi.org/10.1002/hrdq.1074.

Fialho, P., G. Quintini and M. Vandeweyer (2019), "Returns to different forms of job related training: Factoring in informal learning", OECD Social, Employment and Migration Working Papers, No. 231, OECD Publishing, Paris, https://dx.doi.org/10.1787/b21807e9-en.

Francis, B., S. Mani and Q. Wu (2015), “The Impact of Organization Capital on Firm Innovation”, SSRN Electronic Journal, http://dx.doi.org/10.2139/ssrn.2675779.

Frazis, H. and M. Loewenstein (2005), "Reexamining the Returns to Training", Journal of Human Resources, Vol. XL/2, pp. 453-476, http://dx.doi.org/10.3368/jhr.xl.2.453.

Gallié, E. and D. Legros (2011), "Firms' human capital, R\&D and innovation: a study on French firms", Empirical Economics, Vol. 43/2, pp. 581-596, http://dx.doi.org/10.1007/s00181-011-0506-8.

Gittell, J., R. Seidner and J. Wimbush (2010), “A Relational Model of How High-Performance Work Systems Work", Organization Science, Vol. 21/2, pp. 490-506, http://dx.doi.org/10.1287/orsc.1090.0446.

González, X., D. Miles-Touya and C. Pazó (2016), "R\&D, worker training and innovation: firm-level evidence", Industry and Innovation, Vol. 23/8, pp. 694-712, http://dx.doi.org/10.1080/13662716.2016.1206463.

Griffith, R., S. Redding and J. Van Reenen (2004), "Mapping the Two Faces of R\&D: Productivity Growth in a Panel of OECD Industries", Review of Economics and Statistics, Vol. 86/4, pp. 883895, https://doi.org/10.1162/0034653043125194 (accessed on 2 July 2020).

Grundke, R. et al. (2017), "Skills and global value chains: A characterisation", OECD Science, Technology and Industry Working Papers, No. 2017/05, https://dx.doi.org/10.1787/cdb5de9b-en.

Hall, B., F. Lotti and J. Mairesse (2013), "Evidence on the impact of R\&D and ICT investments on innovation and productivity in Italian firms", Economics of Innovation and New Technology, Vol. 22/3, pp. 300-328, http://dx.doi.org/10.1080/10438599.2012.708134.

Hamilton, B., J. Nickerson and H. Owan (2003), “Team Incentives and Worker Heterogeneity: An Empirical Analysis of the Impact of Teams on Productivity and Participation", Journal of Political Economy, Vol. 111/3, pp. 465-497, http://dx.doi.org/10.1086/374182.

Heckman, J. (1979), "Sample Selection Bias as a Specification Error”, Econometrica, Vol. 47/1, p. 153, http://dx.doi.org/10.2307/1912352. 
Holton, E., H. Chen and S. Naquin (2003), “An examination of learning transfer system characteristics across organizational settings", Human Resource Development Quarterly, Vol. 14/4, pp. 459-482, http://dx.doi.org/10.1002/hrdq.1079.

Jona Lasinio, C., M. Iommi and S. Manzocchi (2010), "Intangible Capital and Productivity Growth in European Countries”, SSRN Electronic Journal, http://dx.doi.org/10.2139/ssrn.1691985.

Kelliher, F. and L. Reinl (2009), “A resource-based view of micro-firm management practice”, Journal of Small Business and Enterprise Development, Vol. 16/3, pp. 521-532.

Kim, Y. and Y. Yoon (2008), Case Studies of the Workplace Learning in Small and Medium Enterprises in Korea, Korean Research Institute for Vocational Education and Training.

Kitching, J. (2008), 'Rethinking UK small employers' skills policies and the role of workplace learning", International Journal of Training and Development, Vol. 12/2, pp. 100-120, http://dx.doi.org/10.1111/j.1468-2419.2008.00298.x.

Konings, J. and S. Vanormelingen (2009), “The Impact of Training on Productivity and Wages: Firm Level Evidence”, SSRN Electronic Journal, http://dx.doi.org/10.2139/ssrn.1487468.

Kotey, B. and C. Folker (2007), "Employee Training in SMEs: Effect of Size and Firm Type-Family and Nonfamily", Journal of Small Business Management, Vol. 45/2, pp. 214-238, http://dx.doi.org/10.1111/j.1540-627x.2007.00210.x.

Le Mouel, M. and M. Squicciarini (2015), "Cross-Country Estimates of Employment and Investment in Organisational Capital: A Task-Based Methodology Using Piaac Data”, OECD Science, Technology and Industry Working Papers, No. 2015/8, OECD Publishing, Paris, https://dx.doi.org/10.1787/5jrs3smfgcjb-en.

Leuven, E. and H. Oosterbeek (2008), “An alternative approach to estimate the wage returns to privatesector training”, Journal of Applied Econometrics, Vol. 23/4, pp. 423-434, http://dx.doi.org/10.1002/jae.1005.

Leuven, E. and H. Oosterbeek (2004), "Evaluating the Effect of Tax Deductions on Training", Journal of Labor Economics, Vol. 22/2, pp. 461-488, http://dx.doi.org/10.1086/381257.

Machin, S. and A. Vignoles (2001), "The Economic Benefits of Training to the Individual, the Firm and the Economy: The Key Issues", Centre for the Economics of Education.

Mankiw, N., D. Romer and D. Weil (1992), “A Contribution to the Empirics of Economic Growth", The Quarterly Journal of Economics, Vol. 107/2, pp. 407-437, http://dx.doi.org/10.2307/2118477.

Marrocu, E., R. Paci and M. Pontis (2011), “Intangible capital and firms' productivity”, Industrial and Corporate Change, Vol. 21/2, pp. 377-402, http://dx.doi.org/10.1093/icc/dtr042.

Mason, G., B. O'Leary and M. Vecchi (2012), “Certified and uncertified skills and productivity growth performance: Cross-country evidence at industry level”, Labour Economics, Vol. 19/3, pp. 351-360, http://dx.doi.org/10.1016/j.labeco.2012.03.003.

Mason, G., A. Rincon-Aznar and F. Venturini (2019), "Which skills contribute most to absorptive capacity, innovation and productivity performance? Evidence from the US and Western Europe", Economics of Innovation and New Technology, Vol. 29/3, pp. 223-241, http://dx.doi.org/10.1080/10438599.2019.1610547. 
Mason, G. and K. Wagner (2005), "Restructuring of automotive supply-chains: the role of workforce skills in Germany and Britain", International Journal of Automotive Technology and Management, Vol. 5/4, p. 387, http://dx.doi.org/10.1504/ijatm.2005.008582.

McDougall, M. and R. Beattie (1998), "The missing link? Understanding the relationship between individual and organisational learning", International Journal of Training and Development, Vol. 2/4, pp. 288-299, http://dx.doi.org/10.1111/1468-2419.00055.

Messinis, G. and A. Ahmed (2013), "Cognitive skills, innovation and technology diffusion", Economic Modelling, Vol. 30, pp. 565-578, http://dx.doi.org/10.1016/j.econmod.2012.10.002.

Mincer, J. (1989), "Human Capital and the Labor Market”, Educational Researcher, Vol. 18/4, pp. 2734, http://dx.doi.org/10.3102/0013189x018004027.

Mohnen, P. and L. Röller (2005), "Complementarities in innovation policy", European Economic Review, Vol. 49/6, pp. 1431-1450, http://dx.doi.org/10.1016/j.euroecorev.2003.12.003.

Morgan, R., C. Katsikeas and K. Appiah-Adu (1998), "Market Orientation and Organizational Learning Capabilities", Journal of Marketing Management, Vol. 14/4, pp. 353-381, http://dx.doi.org/10.1362/026725798784959444.

Nikandrou, I., V. Brinia and E. Bereri (2009), “Trainee perceptions of training transfer: an empirical analysis", Journal of European Industrial Training, Vol. 33/3, pp. 255-270, http://dx.doi.org/10.1108/03090590910950604.

Nilsson, A. (2010), "Vocational education and training - an engine for economic growth and a vehicle for social inclusion?", International Journal of Training and Development, Vol. 14/4, pp. 251-272, http://dx.doi.org/10.1111/j.1468-2419.2010.00357.x.

OECD (2017), OECD Skills Outlook 2017: Skills and Global Value Chains, OECD Publishing, Paris, https://dx.doi.org/10.1787/9789264273351-en.

OECD (2016), Skills Matter: Further Results from the Survey of Adult Skills, OECD Skills Studies, OECD Publishing, Paris, https://dx.doi.org/10.1787/9789264258051-en.

Peri, G., K. Shih and C. Sparber (2015), "STEM Workers, H-1B Visas, and Productivity in US Cities", Journal of Labor Economics, Vol. 33/S1, pp. S225-S255, http://dx.doi.org/10.1086/679061.

Pischke, J. (2005), Comments on “Workplace Training in Europe” by Bassanini et al., London School of Economics.

Rao, S., J. Tang and W. Wang (2002), “The Importance of Skills for Innovation and Productivity", https://www.researchgate.net/publication/24051634 (accessed on 6 July 2020).

Romer, P. (1990), "Human capital and growth: Theory and evidence", Carnegie-Rochester Conference Series on Public Policy, Vol. 32, pp. 251-286, http://dx.doi.org/10.1016/0167-2231(90)90028-j.

Rowden, R. and C. Conine (2005), "The impact of workplace learning on job satisfaction in small US commercial banks", Journal of Workplace Learning, Vol. 17/4, pp. 215-230, http://dx.doi.org/10.1108/13665620510597176.

Salthouse, T. and T. Maurer (1996), “Aging, Job Performance, and Career Development”, in Handbook of the psychology of aging. 
Shepherd, C. et al. (2011), "Sales manager training practices in small and large firms", American Journal of Business, Vol. 26/2, pp. 92-117, http://dx.doi.org/10.1108/19355181111174499.

Sinkula, J. (1994), "Market Information Processing and Organizational Learning", Journal of Marketing, Vol. 58/1, p. 35, http://dx.doi.org/10.2307/1252249.

Slater, S. and J. Narver (1995), "Market Orientation and the Learning Organization", Journal of Marketing, Vol. 59/3, p. 63, http://dx.doi.org/10.2307/1252120.

Squicciarini, M. and M. Le Mouel (2012), "Defining and Measuring Investment in Organisational Capital: Using US Microdata to Develop a Task-based Approach", OECD Science, Technology and Industry Working Papers, No. 2012/5, OECD Publishing, Paris, https://dx.doi.org/10.1787/5k92n2t3045b-en.

Squicciarini, M., L. Marcolin and P. Horvát (2015), "Estimating Cross-Country Investment in Training: An Experimental Methodology Using PIAAC Data", OECD Science, Technology and Industry Working Papers, No. 2015/9, OECD Publishing, Paris, https://dx.doi.org/10.1787/5jrs3sftp8nw-en.

Sterlacchini, A. and F. Venturini (2014), "R\&D and Productivity in High-Tech Manufacturing: A Comparison between Italy and Spain", Industry and Innovation, Vol. 21/5, pp. 359-379, http://dx.doi.org/10.1080/13662716.2014.959315.

Tikkanen, T., E. Hovdhaugen and L. Støren (2018), "Work-related training and workplace learning: Nordic perspectives and European comparisons", International Journal of Lifelong Education, Vol. 37/5, pp. 523-526, http://dx.doi.org/10.1080/02601370.2018.1554721.

Toner, P. (2011), "Workforce Skills and Innovation: An Overview of Major Themes in the Literature", OECD Science, Technology and Industry Working Papers, No. 2011/1, OECD Publishing, Paris, https://dx.doi.org/10.1787/5kgkdgdkc8tl-en.

van Smoorenburg, M. and R. van der Velden (2000), "The training of school-leavers", Economics of Education Review, Vol. 19/2, pp. 207-217, http://dx.doi.org/10.1016/s0272-7757(99)00044-8.

Vandenbussche, J., P. Aghion and C. Meghir (2006), "Growth, distance to frontier and composition of human capital", Journal of Economic Growth, Vol. 11/2, pp. 97-127, http://dx.doi.org/10.1007/s10887-006-9002-y.

Werquin, P. (2007), "Moving Mountains: will qualifications systems promote lifelong learning?", European Journal of Education, Vol. 42/4, pp. 459-484, http://dx.doi.org/10.1111/j.14653435.2007.00327.x.

Woodruff, R. (1997), "Customer value: The next source for competitive advantage", Journal of the Academy of Marketing Science, Vol. 25/2, pp. 139-153, http://dx.doi.org/10.1007/bf02894350.

World Bank (2010), Turkey - Investment climate assessment : from crisis to private sector led growth (English)., World Bank.

Wright, P. and G. McMahan (2011), "Exploring human capital: putting 'human' back into strategic human resource management", Human Resource Management Journal, Vol. 21/2, pp. 93-104, http://dx.doi.org/10.1111/j.1748-8583.2010.00165.x.

Zahra, S. and G. George (2002), "Absorptive Capacity: A Review, Reconceptualization, and Extension", The Academy of Management Review, Vol. 27/2, p. 185, http://dx.doi.org/10.2307/4134351. 
Zwick, T. (2006), "The Impact of Training Intensity on Establishment Productivity”, Industrial Relations, Vol. 45/1, pp. 26-46, http://dx.doi.org/10.1111/j.1468-232x.2006.00412.x.

Zwick, T. (2005), "Continuing Vocational Training Forms and Establishment Productivity in

[69] Germany”, German Economic Review, Vol. 6/2, pp. 155-184, http://dx.doi.org/10.1111/j.14656485.2005.00125.x. 


\section{Annex A. Additional Tables and Figures}

Figure A.1. Dendogram

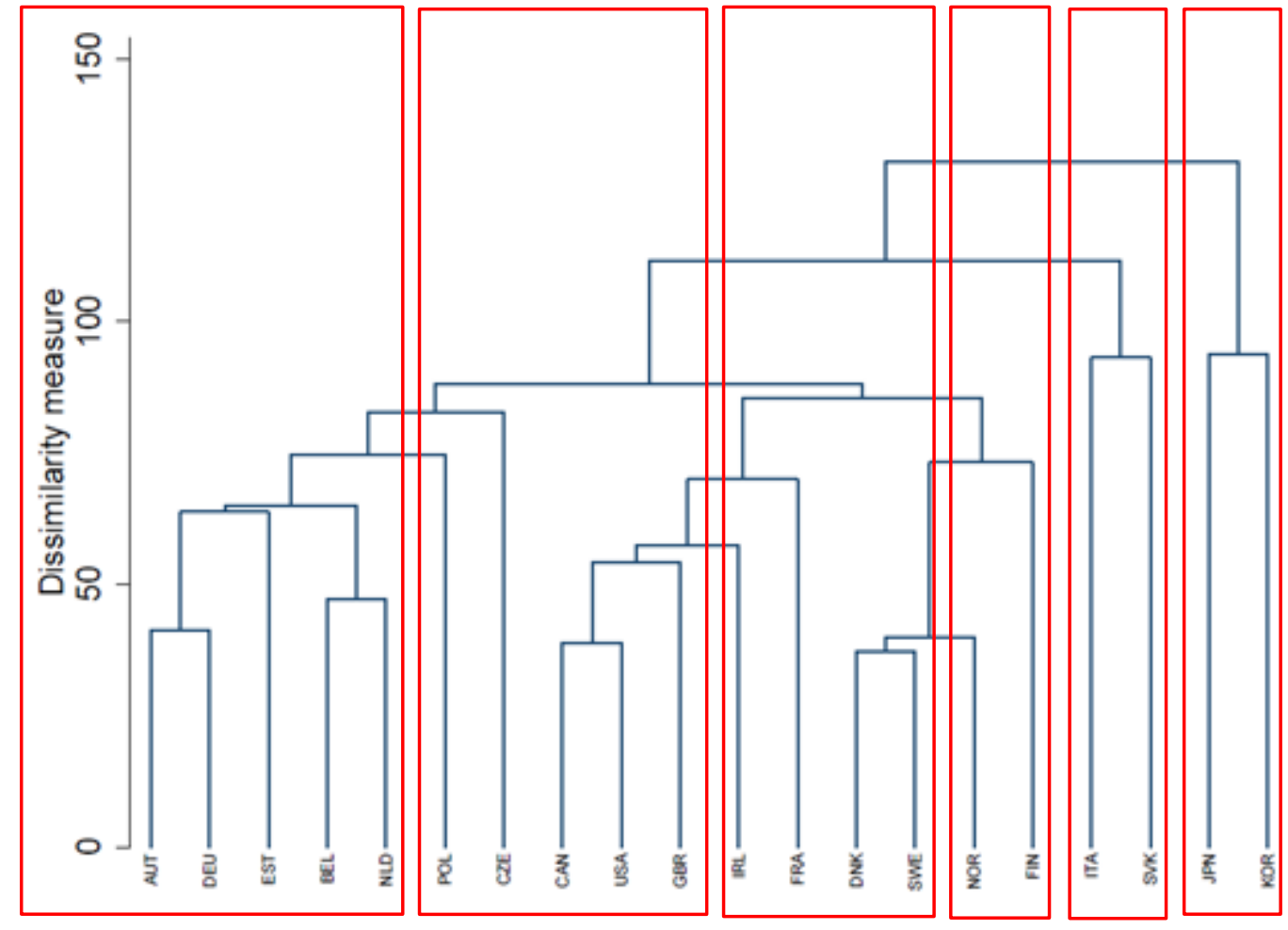

Source: Author's own compilation.

Figure A.2. Histogram

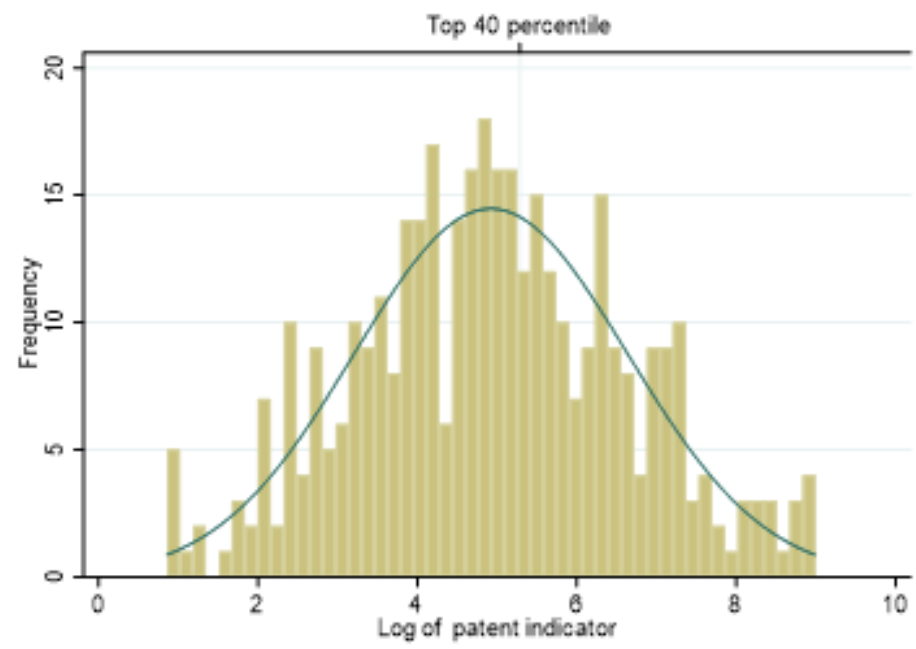

Note: Patent indicator measures the number of patents at the country-industry level weighted by the countryindustry specific matching rate, adjusted by the country-industry specific employee size (in million) and winsorised (top and bottom 1 percent).

Source: Author's own compilation. 
Figure A.3. Scatter plots: investment in training
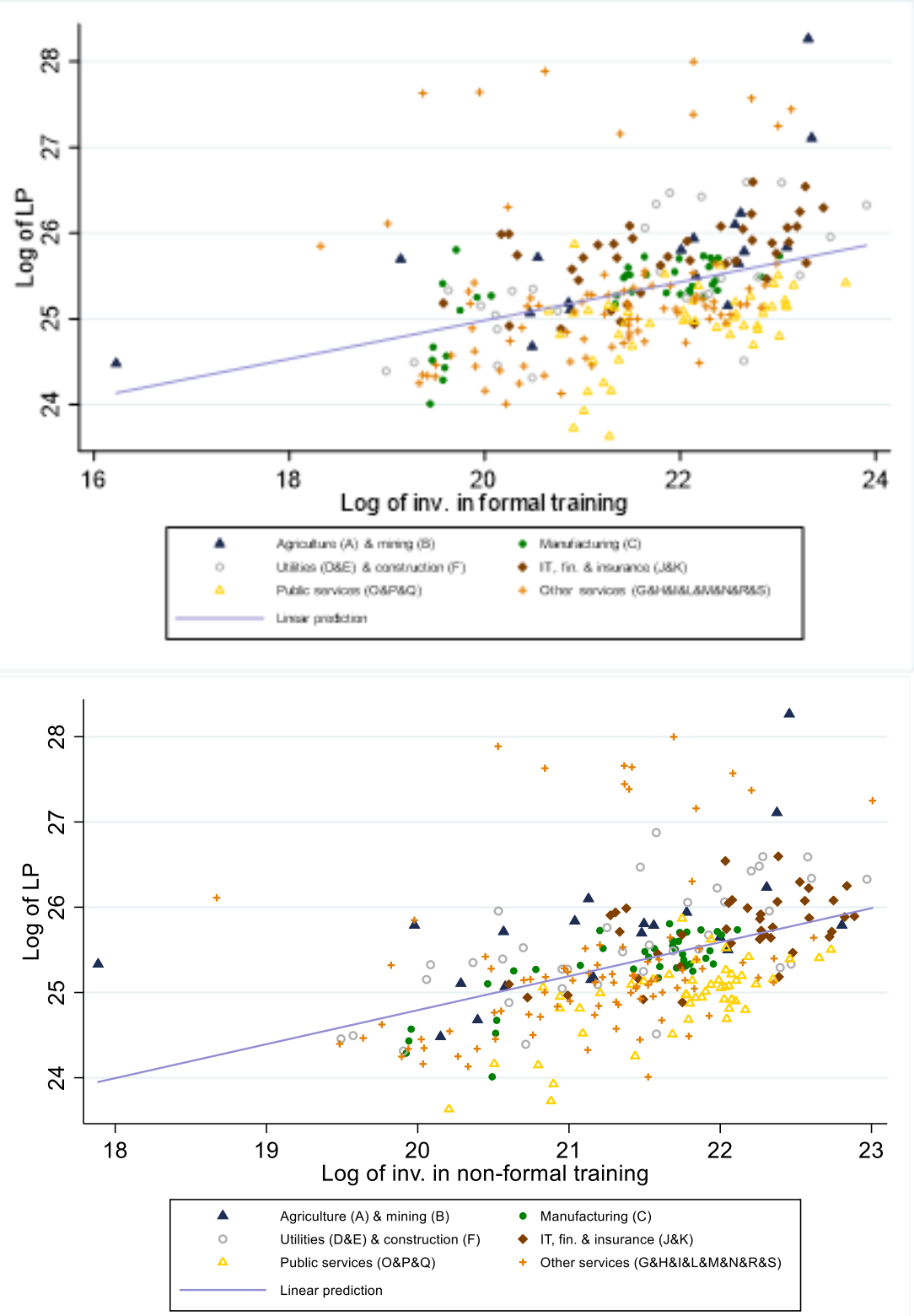

Note: The sample consists of 276 observations with the following 20 countries included: AUT, BEL, CAN, CZE, DEU, DNK, EST, FIN, FRA, GBR, IRL, ITA, JPN, KOR, NLD, NOR, POL, SVK SWE and USA. Source: Author's own compilation 
44 | THE ROLE OF INNOVATION AND HUMAN CAPITAL FOR THE PRODUCTIVITY OF INDUSTRIES

Table A.1. Correlation matrix

\begin{tabular}{|c|c|c|c|c|c|c|c|c|c|c|c|c|c|}
\hline & $\begin{array}{l}\text { Log of } \\
\text { VA/emp }\end{array}$ & $\begin{array}{l}\log \\
\text { patents }\end{array}$ & $\begin{array}{l}\text { Median nu- } \\
\text { meracy }\end{array}$ & $\begin{array}{c}\text { Nu-meracy } \\
\text { (Perc90-median) }\end{array}$ & $\begin{array}{l}\text { Mean } \\
\text { ICT }\end{array}$ & $\begin{array}{l}\text { Mean } \\
\text { STEM }\end{array}$ & $\begin{array}{c}\text { Log of } \\
\text { NFA }\end{array}$ & $\begin{array}{l}\text { Share of } \\
\text { OC }\end{array}$ & $\begin{array}{l}\text { Log total } \\
\text { training }\end{array}$ & $\begin{array}{l}\text { Log formal } \\
\text { training }\end{array}$ & $\begin{array}{l}\text { Log non- } \\
\text { formal training }\end{array}$ & $\begin{array}{l}\text { Log informal } \\
\text { training }\end{array}$ & $\begin{array}{c}\text { Top } 40 \\
\text { inno-vators }\end{array}$ \\
\hline Log of VA/emp & 1.00 & & & & & & & & & & & & \\
\hline Log patents & 0.36 & 1.00 & & & & & & & & & & & \\
\hline Median numeracy & 0.31 & 0.30 & 1.00 & & & & & & & & & & \\
\hline $\begin{array}{l}\text { Numeracy } \\
\text { (Perc90-median) }\end{array}$ & 0.01 & -0.03 & -0.53 & 1.00 & & & & & & & & & \\
\hline Mean ICT & 0.42 & 0.30 & 0.76 & -0.29 & 1.00 & & & & & & & & \\
\hline Mean STEM & 0.23 & 0.36 & 0.65 & -0.25 & 0.67 & 1.00 & & & & & & & \\
\hline Share of OC & -0.04 & 0.01 & 0.30 & -0.09 & 0.46 & 0.26 & -0.13 & 1.00 & & & & & \\
\hline Log total training & 0.49 & 0.20 & 0.36 & 0.03 & 0.50 & 0.14 & 0.25 & 0.20 & 1.00 & & & & \\
\hline $\begin{array}{l}\text { Log formal } \\
\text { training }\end{array}$ & 0.36 & 0.11 & 0.28 & 0.10 & 0.42 & 0.11 & 0.15 & 0.26 & 0.91 & 1.00 & & & \\
\hline $\begin{array}{l}\text { Log non-formal } \\
\text { training }\end{array}$ & 0.47 & 0.25 & 0.41 & -0.05 & 0.56 & 0.22 & 0.25 & 0.17 & 0.90 & 0.71 & 1.00 & & \\
\hline $\begin{array}{l}\text { Log informal } \\
\text { training }\end{array}$ & 0.52 & 0.26 & 0.24 & 0.05 & 0.30 & 0.00 & 0.19 & 0.09 & 0.80 & 0.65 & 0.65 & 1.00 & \\
\hline Top 40 innovators & 0.21 & 0.74 & 0.29 & -0.07 & 0.35 & 0.40 & -0.04 & 0.08 & 0.06 & 0.01 & 0.13 & 0.11 & 1.00 \\
\hline
\end{tabular}

Note: The sample consists of 263 observations. R\&D expenditure is excluded as it is not available for the whole sample and only used in our main models. Source: Author's own compilation 
Table A.2. Full results: estimation results using OLS

\begin{tabular}{|c|c|c|c|c|c|}
\hline & (1) & (2) & (3) & (4) & (5) \\
\hline \multirow[t]{2}{*}{ Log patents } & $0.055^{* *}$ & $0.062^{\star *}$ & $0.059^{* *}$ & $0.038^{*}$ & $0.040^{*}$ \\
\hline & $(0.022)$ & $(0.022)$ & $(0.022)$ & $(0.022)$ & $(0.021)$ \\
\hline \multirow[t]{2}{*}{ Mean ICT skill score } & 0.008 & $0.012^{*}$ & 0.008 & $0.012^{*}$ & $0.011^{*}$ \\
\hline & $(0.007)$ & $(0.007)$ & $(0.007)$ & $(0.006)$ & $(0.006)$ \\
\hline \multirow[t]{2}{*}{ Mean STEM skill score } & -0.006 & -0.011 & -0.011 & -0.001 & 0.001 \\
\hline & $(0.007)$ & $(0.008)$ & $(0.008)$ & $(0.008)$ & $(0.007)$ \\
\hline \multirow[t]{2}{*}{ Median numeracy skill score } & 0.011 & 0.014 & 0.014 & 0.003 & 0.001 \\
\hline & $(0.023)$ & $(0.023)$ & $(0.026)$ & $(0.022)$ & $(0.021)$ \\
\hline \multirow[t]{2}{*}{ Difference between top 10 percentile and median numeracy skill score } & $0.045^{*}$ & $0.048^{* *}$ & $0.049^{* *}$ & $0.042^{*}$ & $0.041^{*}$ \\
\hline & $(0.022)$ & $(0.021)$ & $(0.023)$ & $(0.021)$ & $(0.021)$ \\
\hline \multirow[t]{2}{*}{ Proportion of OC workers } & $0.004^{* \star \star}$ & $0.004^{* *}$ & $0.005^{\star \star *}$ & $0.004^{* *}$ & $0.004^{\star *}$ \\
\hline & $(0.001)$ & $(0.002)$ & $(0.002)$ & $(0.002)$ & $(0.002)$ \\
\hline \multirow[t]{2}{*}{ Log net fixed assets } & $0.375^{\star \star \star}$ & $0.379^{* * *}$ & $0.380^{* * *}$ & $0.382^{* \star *}$ & $0.370^{* * *}$ \\
\hline & $(0.019)$ & $(0.018)$ & $(0.021)$ & $(0.018)$ & $(0.016)$ \\
\hline \multirow[t]{2}{*}{ Log training (total) } & $0.206^{\star \star *}$ & & & & \\
\hline & $(0.045)$ & & & & \\
\hline \multirow[t]{2}{*}{ Log formal training } & & $0.091^{* * *}$ & & & 0.001 \\
\hline & & $(0.025)$ & & & $(0.022)$ \\
\hline \multirow[t]{2}{*}{ Log non-formal training } & & & $0.169^{* \star *}$ & & 0.045 \\
\hline & & & $(0.042)$ & & $(0.051)$ \\
\hline \multirow[t]{2}{*}{ Log informal training } & & & & $0.271^{\star * *}$ & $0.250^{\star \star \star}$ \\
\hline & & & & $(0.044)$ & $(0.045)$ \\
\hline \multirow[t]{2}{*}{ Country cluster 2} & -0.099 & -0.094 & -0.087 & -0.102 & -0.099 \\
\hline & $(0.118)$ & $(0.120)$ & $(0.117)$ & $(0.103)$ & $(0.102)$ \\
\hline \multirow[t]{2}{*}{ Country cluster 3} & -0.156 & $-0.197^{*}$ & $-0.197^{*}$ & -0.127 & -0.127 \\
\hline & $(0.107)$ & $(0.106)$ & $(0.100)$ & $(0.099)$ & $(0.094)$ \\
\hline \multirow[t]{2}{*}{ Country cluster 4} & -0.020 & -0.080 & -0.099 & -0.125 & -0.070 \\
\hline & $(0.229)$ & $(0.238)$ & $(0.228)$ & $(0.183)$ & $(0.190)$ \\
\hline \multirow[t]{2}{*}{ Country cluster 5} & -0.176 & -0.191 & -0.257 & -0.042 & -0.121 \\
\hline & $(0.177)$ & $(0.172)$ & $(0.169)$ & $(0.098)$ & $(0.129)$ \\
\hline \multirow[t]{2}{*}{ Industry cluster 2} & $0.320^{* \star *}$ & $0.284^{* *}$ & $0.227^{* *}$ & $0.370^{* * *}$ & $0.347^{* * *}$ \\
\hline & $(0.105)$ & $(0.105)$ & $(0.107)$ & $(0.117)$ & $(0.112)$ \\
\hline \multirow[t]{2}{*}{ Industry cluster 3} & $0.222^{*}$ & $0.223^{*}$ & 0.143 & 0.188 & $0.211^{*}$ \\
\hline & $(0.110)$ & $(0.113)$ & $(0.110)$ & $(0.120)$ & $(0.115)$ \\
\hline \multirow[t]{2}{*}{ Industry cluster 4} & 0.010 & -0.003 & -0.047 & -0.057 & -0.072 \\
\hline & $(0.204)$ & $(0.210)$ & $(0.201)$ & $(0.206)$ & $(0.199)$ \\
\hline \multirow[t]{2}{*}{ Industry cluster 5} & $-0.455^{\star *}$ & $-0.496^{* *}$ & $-0.524^{\star \star \star}$ & $-0.400^{* *}$ & $-0.403^{\star *}$ \\
\hline & $(0.187)$ & $(0.205)$ & $(0.183)$ & $(0.183)$ & $(0.187)$ \\
\hline \multirow[t]{2}{*}{ Industry cluster 6} & 0.023 & -0.055 & -0.061 & 0.040 & 0.039 \\
\hline & $(0.120)$ & $(0.130)$ & $(0.125)$ & $(0.137)$ & $(0.132)$ \\
\hline \multirow[t]{2}{*}{ Constant } & $9.574^{* \star *}$ & $12.030^{* * *}$ & $10.520^{* * \star}$ & $8.512^{\star \star *}$ & $8.287^{\text {** }}$ \\
\hline & $(1.597)$ & $(1.387)$ & $(1.681)$ & $(1.118)$ & $(1.300)$ \\
\hline Observations & 263 & 263 & 276 & 276 & 263 \\
\hline R-squared & 0.83 & 0.82 & 0.83 & 0.85 & 0.85 \\
\hline
\end{tabular}

Note: The country clusters include: 1) CAN, FRA, GBR, IRL and USA; 2) DNK, FIN, NOR and SWE; 3) AUT, BEL, CZE, DEU, EST, NLD and POL; 4) ITA and SVK; 5) JPN and KOR with cluster 1) being the reference group omitted from the regression. The industry clusters include: 1) agriculture, forestry and fishing (A) and mining and quarrying (B); 2) manufacturing (C); 3) utilities (D \& E) and construction (F); 4) information and communication (J) and financial and insurance activities (K); 5) public services (O \& P \& Q) and 6) other business, social and personal services ( $G$ \& H \& I \& L \& M \& N \& R \& S) with 1) being the reference group. Robust standard errors are clustered at the country level. *,**, and *** indicate that coefficients are significant at the $10 \%, 5 \%$ and $1 \%$ levels, respectively. Source: Author's own compilation. 
Table A.3. Full results: estimation results addressing self-selection

\begin{tabular}{|c|c|c|c|c|c|c|c|c|c|c|}
\hline & $\begin{array}{l}\text { Selection } \\
\text { (1a) }\end{array}$ & $\begin{array}{l}\text { LP } \\
\text { (1b) }\end{array}$ & $\begin{array}{l}\text { Selection } \\
\text { (2a) }\end{array}$ & $\begin{array}{l}\mathrm{LP} \\
(2 \mathrm{~b})\end{array}$ & $\begin{array}{c}\text { Selection } \\
\text { (3a) }\end{array}$ & $\begin{array}{l}\mathrm{LP} \\
(3 \mathrm{~b})\end{array}$ & $\begin{array}{c}\text { Selection } \\
\text { (4a) }\end{array}$ & $\begin{array}{l}\mathrm{LP} \\
(4 \mathrm{~b})\end{array}$ & $\begin{array}{l}\text { Selection } \\
(5 a)\end{array}$ & $\begin{array}{l}\mathrm{LP} \\
(5 b)\end{array}$ \\
\hline \multirow[t]{2}{*}{ Log R\&D } & $0.304^{* \star *}$ & & $0.327^{\star * *}$ & & $0.240^{\star \star *}$ & & $0.228^{\star \star \star}$ & & $0.318^{\star \star *}$ & \\
\hline & $(0.087)$ & & $(0.091)$ & & $(0.080)$ & & $(0.081)$ & & $(0.094)$ & \\
\hline \multirow[t]{2}{*}{ IMR } & & -0.054 & & $-0.075^{*}$ & & -0.052 & & -0.054 & & -0.058 \\
\hline & & $(0.036)$ & & $(0.037)$ & & $(0.037)$ & & $(0.034)$ & & $(0.034)$ \\
\hline \multirow[t]{2}{*}{ Log patents } & & $0.056^{*}$ & & $0.067^{* *}$ & & $0.055^{*}$ & & 0.046 & & 0.045 \\
\hline & & $(0.029)$ & & $(0.029)$ & & $(0.028)$ & & $(0.026)$ & & $(0.027)$ \\
\hline Mean ICT skill score & $0.159^{* \star *}$ & 0.006 & $0.165^{* * *}$ & 0.009 & $0.125^{\star * *}$ & 0.007 & $0.110^{* * *}$ & $0.011^{* *}$ & $0.164^{* \star *}$ & 0.009 \\
\hline \multirow[t]{2}{*}{ Mean STEM skill score } & 0.023 & -0.006 & 0.024 & -0.011 & 0.039 & -0.007 & 0.049 & 0.001 & 0.029 & -0.000 \\
\hline & $(0.035)$ & $(0.009)$ & $(0.035)$ & $(0.009)$ & $(0.033)$ & $(0.009)$ & $(0.035)$ & $(0.009)$ & $(0.037)$ & $(0.008)$ \\
\hline \multirow[t]{2}{*}{ Median numeracy skill score } & -0.082 & 0.026 & -0.073 & 0.031 & -0.088 & 0.020 & -0.093 & 0.004 & -0.079 & 0.015 \\
\hline & $(0.090)$ & $(0.021)$ & $(0.093)$ & $(0.021)$ & $(0.084)$ & $(0.020)$ & $(0.084)$ & $(0.018)$ & $(0.094)$ & $(0.021)$ \\
\hline \multirow[t]{2}{*}{ Difference between top 10 percentile and median numeracy skill score } & 0.025 & 0.038 & 0.058 & $0.045^{\star}$ & 0.037 & $0.044^{*}$ & 0.022 & 0.031 & 0.053 & 0.031 \\
\hline & $(0.117)$ & $(0.023)$ & $(0.122)$ & $(0.022)$ & $(0.108)$ & $(0.024)$ & $(0.109)$ & $(0.024)$ & $(0.123)$ & $(0.023)$ \\
\hline \multirow[t]{2}{*}{ Proportion of OC workers } & 0.001 & $0.003^{*}$ & 0.003 & $0.003^{*}$ & 0.001 & $0.004^{\star \star}$ & 0.002 & $0.003^{*}$ & 0.003 & 0.003 \\
\hline & $(0.010)$ & $(0.002)$ & $(0.010)$ & $(0.002)$ & $(0.010)$ & $(0.002)$ & $(0.009)$ & $(0.002)$ & $(0.010)$ & $(0.002)$ \\
\hline Log net fixed assets & $(0.107)$ & $(0.026)$ & $(0.109)$ & $(0.024)$ & $(0.103)$ & $(0.024)$ & $(0.103)$ & $(0.019)$ & $(0.111)$ & $(0.022)$ \\
\hline \multirow[t]{2}{*}{ Log training (total) } & $-0.767^{\star \star *}$ & $0.190^{* * *}$ & & & & & & & & \\
\hline & $(0.264)$ & $(0.055)$ & & & & & & & & \\
\hline \multirow[t]{2}{*}{ Log formal training } & & & $-0.590^{\star * \star}$ & $0.072^{\star \star \star}$ & & & & & $-0.596^{* \star *}$ & -0.000 \\
\hline & & & $(0.165)$ & $(0.024)$ & & & & & $(0.184)$ & $(0.024)$ \\
\hline \multirow[t]{2}{*}{ Log non-formal training } & & & & & -0.344 & $0.179^{\star \star \star}$ & & & -0.032 & 0.066 \\
\hline & & & & & $(0.221)$ & $(0.053)$ & & & $(0.306)$ & $(0.055)$ \\
\hline \multirow[t]{2}{*}{ Log informal training } & & & & & & & -0.045 & $0.264^{* * *}$ & 0.130 & $0.217^{\star * \star}$ \\
\hline & & & & & & & $(0.268)$ & $(0.045)$ & $(0.351)$ & $(0.050)$ \\
\hline \multirow[t]{2}{*}{ Country cluster 2} & -0.056 & -0.191 & -0.130 & -0.190 & 0.091 & -0.145 & 0.097 & -0.129 & -0.112 & -0.176 \\
\hline & $(0.462)$ & $(0.120)$ & $(0.479)$ & $(0.121)$ & $(0.425)$ & $(0.109)$ & $(0.418)$ & $(0.106)$ & $(0.482)$ & $(0.113)$ \\
\hline Country cluster 3 & 0.426 & $-0.247^{\star *}$ & 0.418 & $-0.290^{* * *}$ & 0.652 & $-0.247^{* *}$ & $0.696^{*}$ & $-0.179^{*}$ & 0.462 & $-0.219^{* *}$ \\
\hline
\end{tabular}

OECD SCIENCE, TECHNOLOGY AND INDUSTRY POLICY PAPERS 


\begin{tabular}{|c|c|c|c|c|c|c|c|c|c|c|}
\hline & $(0.426)$ & $(0.100)$ & $(0.438)$ & $(0.100)$ & $(0.403)$ & $(0.092)$ & $(0.408)$ & $(0.093)$ & $(0.454)$ & $(0.095)$ \\
\hline \multirow[t]{2}{*}{ Country cluster 4} & 0.093 & 0.069 & -0.004 & 0.002 & 0.427 & 0.054 & 0.652 & -0.036 & -0.010 & 0.014 \\
\hline & $(0.565)$ & $(0.179)$ & $(0.562)$ & $(0.183)$ & $(0.538)$ & $(0.155)$ & $(0.522)$ & $(0.126)$ & $(0.566)$ & $(0.147)$ \\
\hline Country cluster 5 & $1.308^{* *}$ & $-0.306^{*}$ & 0.909 & $-0.328^{\star *}$ & $1.407^{* \star}$ & $-0.376^{* *}$ & $1.324^{* *}$ & $-0.171^{*}$ & 0.985 & $-0.264^{* *}$ \\
\hline \multirow[t]{2}{*}{ Industry cluster 2} & 0.956 & $0.383^{\star \star \star}$ & $1.274^{*}$ & $0.351^{* \star \star}$ & $1.194^{*}$ & $0.260^{\star *}$ & $1.120^{*}$ & $0.388^{\star \star *}$ & $1.348^{*}$ & $0.397^{* * *}$ \\
\hline & $(0.644)$ & $(0.116)$ & $(0.702)$ & $(0.121)$ & $(0.611)$ & $(0.120)$ & $(0.612)$ & $(0.122)$ & $(0.737)$ & $(0.118)$ \\
\hline \multirow[t]{2}{*}{ Industry cluster 3} & $-2.241^{* *}$ & $0.274^{* *}$ & $-1.942^{* *}$ & $0.288^{* *}$ & $-1.809^{* *}$ & 0.176 & $-1.794^{* *}$ & 0.213 & $-1.880^{*}$ & $0.255^{\star}$ \\
\hline & $(0.929)$ & $(0.123)$ & $(0.953)$ & $(0.123)$ & $(0.736)$ & $(0.128)$ & $(0.720)$ & $(0.128)$ & $(0.968)$ & $(0.123)$ \\
\hline \multirow[t]{2}{*}{ Industry cluster 4} & $-2.451^{* *}$ & 0.022 & $-2.428^{\star *}$ & 0.027 & $-1.781^{*}$ & -0.071 & $-1.782^{*}$ & -0.050 & $-2.383^{\star *}$ & -0.045 \\
\hline & $(1.035)$ & $(0.239)$ & $(1.058)$ & $(0.246)$ & $(0.938)$ & $(0.241)$ & $(0.933)$ & $(0.227)$ & $(1.064)$ & $(0.220)$ \\
\hline \multirow[t]{2}{*}{ Industry cluster 5} & -0.851 & -0.368 & -0.379 & -0.375 & -0.698 & $-0.485^{\star}$ & -0.764 & -0.327 & -0.310 & -0.323 \\
\hline & $(1.027)$ & $(0.229)$ & $(1.087)$ & $(0.245)$ & $(0.974)$ & $(0.234)$ & $(0.969)$ & $(0.207)$ & $(1.107)$ & $(0.215)$ \\
\hline \multirow[t]{2}{*}{ Industry cluster 6} & -0.724 & 0.077 & -0.366 & 0.017 & -0.272 & -0.035 & -0.177 & 0.068 & -0.292 & 0.100 \\
\hline & $(0.764)$ & $(0.145)$ & $(0.795)$ & $(0.158)$ & $(0.698)$ & $(0.159)$ & $(0.700)$ & $(0.152)$ & $(0.828)$ & $(0.145)$ \\
\hline \multirow[t]{2}{*}{ Constant } & $9.204^{* * *}$ & $15.980^{* \star *}$ & 7.694 & $11.070^{\star \star \star}$ & 2.742 & $9.631^{* * *}$ & -2.610 & $8.342^{* \star *}$ & 6.096 & $7.653^{\star \star \star}$ \\
\hline & $(2.287)$ & $(1.424)$ & (6.001) & $(1.440)$ & $(6.368)$ & $(1.579)$ & $(6.697)$ & $(1.317)$ & $(7.801)$ & $(1.641)$ \\
\hline
\end{tabular}

Note: The country clusters include: 1) CAN, FRA, GBR, IRL and USA; 2) DNK, FIN, NOR and SWE; 3) AUT, BEL, CZE, DEU, EST, NLD and POL; 4) ITA and SVK; 5) JPN and KOR with cluster 1) being the reference group omitted from the regression. The industry clusters include: 1) agriculture, forestry and fishing (A) and mining and quarrying (B); 2) manufacturing (C); 3) utilities (D \& E) and construction (F); 4) information and communication (J) and financial and insurance activities (K); 5) public services ( $\&$ P \& Q) and 6) other business, social and personal services ( $\mathrm{G} \& \mathrm{H} \& \mathrm{I} \& \mathrm{~L} \& \mathrm{M} \& \mathrm{~N} \& \mathrm{R} \& \mathrm{~S})$ with 1$)$ being the reference group. Robust standard errors are clustered at the country level. *,**, and *** indicate that coefficients are significant at the $10 \%, 5 \%$ and $1 \%$ levels, respectively.

Source: Author's own compilation. 
Table A.4. Full results: estimation results with different fixed effects

\begin{tabular}{|c|c|c|c|c|c|c|c|}
\hline & (1) & (2) & (3) & (4) & (5) & (6) & (7) \\
\hline \multirow[t]{2}{*}{ Log patents } & $0.129^{\star \star \star}$ & $0.089^{* * *}$ & $0.047^{*}$ & $0.028^{*}$ & $0.129^{\star \star \star}$ & $0.053^{* *}$ & $0.055^{\star *}$ \\
\hline & $(0.018)$ & $(0.016)$ & $(0.026)$ & $(0.016)$ & $(0.017)$ & $(0.022)$ & $(0.022)$ \\
\hline \multirow[t]{2}{*}{ Mean ICT skill score } & -0.002 & 0.002 & 0.005 & 0.003 & -0.003 & 0.010 & 0.008 \\
\hline & $(0.007)$ & $(0.005)$ & $(0.009)$ & $(0.006)$ & $(0.005)$ & $(0.007)$ & $(0.007)$ \\
\hline \multirow[t]{2}{*}{ Mean STEM skill score } & 0.007 & $0.050^{* * *}$ & $-0.018^{* *}$ & $0.018^{* *}$ & 0.005 & -0.005 & -0.006 \\
\hline & $(0.007)$ & $(0.008)$ & $(0.006)$ & $(0.007)$ & $(0.006)$ & $(0.008)$ & $(0.007)$ \\
\hline \multirow[t]{2}{*}{ Median numeracy skill score } & 0.002 & $-0.052^{* *}$ & 0.017 & 0.009 & 0.014 & -0.004 & 0.011 \\
\hline & $(0.023)$ & $(0.020)$ & $(0.020)$ & $(0.015)$ & $(0.023)$ & $(0.018)$ & $(0.023)$ \\
\hline \multirow{2}{*}{$\begin{array}{l}\text { Difference between top } 10 \text { percentile and median numeracy } \\
\text { skill score }\end{array}$} & $0.068^{* \star}$ & -0.008 & $0.066^{\star \star *}$ & 0.013 & $0.054^{* *}$ & $0.052^{* \star}$ & $0.045^{\star}$ \\
\hline & $(0.031)$ & $(0.024)$ & $(0.021)$ & $(0.015)$ & $(0.025)$ & $(0.024)$ & $(0.022)$ \\
\hline \multirow[t]{2}{*}{ Proportion of OC workers } & 0.000 & $-0.004^{* *}$ & $0.004^{*}$ & 0.000 & -0.001 & $0.005^{\star *}$ & $0.004^{\star * *}$ \\
\hline & $(0.002)$ & $(0.002)$ & $(0.002)$ & $(0.002)$ & $(0.002)$ & $(0.002)$ & $(0.001)$ \\
\hline \multirow[t]{2}{*}{ Log net fixed assets } & $0.367^{* * *}$ & $0.346^{* \star *}$ & $0.275^{\star \star *}$ & $0.221^{* * *}$ & $0.367^{* * *}$ & $0.374^{* * *}$ & $0.375^{\star * *}$ \\
\hline & $(0.022)$ & $(0.018)$ & $(0.058)$ & $(0.037)$ & $(0.020)$ & $(0.020)$ & $(0.019)$ \\
\hline \multirow[t]{2}{*}{ Log training investment } & $0.224^{* \star *}$ & -0.017 & $0.266^{\star * *}$ & $0.113^{*}$ & $0.194^{\star * *}$ & $0.229^{\star \star *}$ & $0.206^{\star \star *}$ \\
\hline & $(0.053)$ & $(0.045)$ & $(0.050)$ & $(0.055)$ & $(0.046)$ & $(0.049)$ & $(0.045)$ \\
\hline \multirow[t]{2}{*}{ AUT } & & $0.990^{* * *}$ & & $-0.271^{* * *}$ & & & \\
\hline & & $(0.117)$ & & $(0.074)$ & & & \\
\hline \multirow[t]{2}{*}{ BEL } & & $1.276^{* * *}$ & & $-0.126^{* *}$ & & & \\
\hline & & $(0.130)$ & & $(0.055)$ & & & \\
\hline \multirow[t]{2}{*}{ CAN } & & $1.297^{* \star *}$ & & $-0.126^{*}$ & & & \\
\hline & & $(0.111)$ & & $(0.073)$ & & & \\
\hline \multirow[t]{2}{*}{ CZE } & & omitted & & $-0.962^{\star * *}$ & & & \\
\hline & & & & $(0.143)$ & & & \\
\hline \multirow[t]{2}{*}{ DEU } & & $0.772^{* * *}$ & & $-0.400^{* * *}$ & & & \\
\hline & & $(0.079)$ & & $(0.095)$ & & & \\
\hline \multirow[t]{2}{*}{ DNK } & & $1.108^{* * *}$ & & $-0.319^{\star \star *}$ & & & \\
\hline & & $(0.142)$ & & $(0.033)$ & & & \\
\hline \multirow[t]{2}{*}{ EST } & & $0.471^{* * *}$ & & $-0.859^{* * *}$ & & & \\
\hline & & $(0.071)$ & & $(0.111)$ & & & \\
\hline \multirow[t]{2}{*}{ FIN } & & $0.866^{* \star *}$ & & $-0.383^{* * *}$ & & & \\
\hline & & $(0.092)$ & & $(0.064)$ & & & \\
\hline \multirow[t]{2}{*}{ FRA } & & $1.160^{\star \star \star}$ & & -0.049 & & & \\
\hline & & $(0.100)$ & & $(0.107)$ & & & \\
\hline \multirow[t]{2}{*}{ GBR } & & $0.934^{* * *}$ & & $-0.364^{* * *}$ & & & \\
\hline & & $(0.113)$ & & $(0.074)$ & & & \\
\hline \multirow[t]{2}{*}{ IRL } & & $1.139^{* * *}$ & & -0.089 & & & \\
\hline & & $(0.131)$ & & $(0.095)$ & & & \\
\hline \multirow[t]{2}{*}{ ITA } & & $1.150^{* * *}$ & & 0.002 & & & \\
\hline & & $(0.098)$ & & $(0.140)$ & & & \\
\hline \multirow[t]{2}{*}{ JPN } & & $1.161^{* * *}$ & & $-0.162^{*}$ & & & \\
\hline & & $(0.133)$ & & $(0.088)$ & & & \\
\hline KOR & & $0.258^{\star *}$ & & $-0.768^{\star * *}$ & & & \\
\hline & & $(0.098)$ & & $(0.128)$ & & & \\
\hline NLD & & $1.298^{\star \star *}$ & & $-0.253^{\star \star *}$ & & & \\
\hline & & $(0.151)$ & & $(0.027)$ & & & \\
\hline NOR & & $1.545^{* * *}$ & & omitted & & & \\
\hline
\end{tabular}




\begin{tabular}{|c|c|c|c|c|c|c|}
\hline & $(0.150)$ & & & & & \\
\hline \multirow[t]{2}{*}{ POL } & $0.510^{* * *}$ & & $-0.802^{* * *}$ & & & \\
\hline & $(0.050)$ & & $(0.151)$ & & & \\
\hline \multirow[t]{2}{*}{ SVK } & $0.513^{* * *}$ & & $-0.797^{* * *}$ & & & \\
\hline & $(0.066)$ & & $(0.120)$ & & & \\
\hline \multirow[t]{2}{*}{ SWE } & $1.298^{* * *}$ & & $-0.176^{\star * *}$ & & & \\
\hline & $(0.138)$ & & $(0.056)$ & & & \\
\hline \multirow[t]{2}{*}{ USA } & $0.842^{* * *}$ & & $-0.283^{* * *}$ & & & \\
\hline & $(0.098)$ & & $(0.092)$ & & & \\
\hline \multirow[t]{2}{*}{ Mining and quarrying } & & $0.797^{\star \star *}$ & $0.598^{* *}$ & & & \\
\hline & & $(0.263)$ & $(0.240)$ & & & \\
\hline \multirow[t]{2}{*}{ Food \& textile } & & 0.103 & 0.001 & & & \\
\hline & & $(0.165)$ & $(0.099)$ & & & \\
\hline \multirow[t]{2}{*}{ Chemicals \& basic metals } & & $0.518^{* *}$ & $0.241^{*}$ & & & \\
\hline & & $(0.224)$ & $(0.136)$ & & & \\
\hline \multirow[t]{2}{*}{ PC, machinery \& repairs } & & $0.465^{*}$ & 0.189 & & & \\
\hline & & $(0.257)$ & $(0.162)$ & & & \\
\hline \multirow[t]{2}{*}{ Utilities } & & $0.378^{* *}$ & $0.320^{* *}$ & & & \\
\hline & & $(0.152)$ & $(0.131)$ & & & \\
\hline \multirow[t]{2}{*}{ Construction } & & 0.286 & 0.061 & & & \\
\hline & & $(0.169)$ & $(0.137)$ & & & \\
\hline \multirow[t]{2}{*}{ Wholesale \& retail } & & 0.012 & -0.039 & & & \\
\hline & & $(0.212)$ & $(0.172)$ & & & \\
\hline \multirow[t]{2}{*}{ Transportation \& accom. } & & -0.014 & -0.108 & & & \\
\hline & & $(0.139)$ & $(0.109)$ & & & \\
\hline \multirow[t]{2}{*}{ ICT } & & 0.161 & -0.053 & & & \\
\hline & & $(0.295)$ & $(0.233)$ & & & \\
\hline \multirow[t]{2}{*}{ Finance \& insurance } & & 0.404 & 0.160 & & & \\
\hline & & $(0.296)$ & $(0.244)$ & & & \\
\hline \multirow[t]{2}{*}{ Real estate activities } & & $0.915^{\star \star *}$ & $0.981^{* * *}$ & & & \\
\hline & & $(0.274)$ & $(0.205)$ & & & \\
\hline \multirow[t]{2}{*}{ Other business sector } & & 0.064 & -0.080 & & & \\
\hline & & $(0.257)$ & $(0.192)$ & & & \\
\hline \multirow[t]{2}{*}{ Public admin. \& defence } & & -0.346 & $-0.404^{*}$ & & & \\
\hline & & $(0.230)$ & $(0.198)$ & & & \\
\hline \multirow[t]{2}{*}{ Education } & & -0.425 & $-0.520^{* *}$ & & & \\
\hline & & $(0.266)$ & $(0.213)$ & & & \\
\hline \multirow[t]{2}{*}{ Health \& social work } & & -0.321 & -0.263 & & & \\
\hline & & $(0.216)$ & $(0.178)$ & & & \\
\hline \multirow[t]{2}{*}{ Other social/personal ser. } & & -0.159 & -0.196 & & & \\
\hline & & $(0.228)$ & $(0.175)$ & & & \\
\hline \multirow[t]{2}{*}{ Country cluster 2} & & & & -0.078 & & -0.100 \\
\hline & & & & $(0.117)$ & & $(0.118)$ \\
\hline Country cluster 3 & & & & -0.156 & & -0.156 \\
\hline & & & & $(0.102)$ & & $(0.107)$ \\
\hline Country cluster 4 & & & & 0.045 & & -0.200 \\
\hline & & & & $(0.201)$ & & $(0.229)$ \\
\hline Country cluster 5 & & & & -0.312 & & -0.176 \\
\hline & & & & $(0.189)$ & & $(0.177)$ \\
\hline Industry cluster 2 & & & & & $0.330^{* \star *}$ & $0.320^{\star \star *}$ \\
\hline
\end{tabular}




\begin{tabular}{|c|c|c|c|c|c|c|c|}
\hline & & & & & & $(0.113)$ & $(0.105)$ \\
\hline \multirow[t]{2}{*}{ Industry cluster 3} & & & & & & $0.205^{*}$ & $0.222^{*}$ \\
\hline & & & & & & $(0.110)$ & $(0.110)$ \\
\hline \multirow[t]{2}{*}{ Industry cluster 4} & & & & & & 0.009 & 0.010 \\
\hline & & & & & & $(0.217)$ & $(0.204)$ \\
\hline \multirow[t]{2}{*}{ Industry cluster 5} & & & & & & $-0.487^{* *}$ & $-0.455^{\star *}$ \\
\hline & & & & & & $(0.191)$ & $(0.187)$ \\
\hline \multirow[t]{2}{*}{ Industry cluster 6} & & & & & & 0.005 & 0.023 \\
\hline & & & & & & $(0.125)$ & $(0.120)$ \\
\hline \multirow[t]{2}{*}{ Constant } & $9.204^{* * *}$ & $15.980^{* * *}$ & $10.820^{* * *}$ & $15.620^{* * *}$ & $9.582^{* * *}$ & $9.589^{* * *}$ & $9.574^{* * *}$ \\
\hline & $(2.287)$ & $(1.424)$ & $(1.856)$ & $(1.539)$ & $(1.563)$ & $(1.665)$ & $(1.597)$ \\
\hline Observations & 263 & 263 & 263 & 263 & 263 & 263 & 263 \\
\hline R-squared & 0.77 & 0.86 & 0.88 & 0.94 & 0.78 & 0.82 & 0.83 \\
\hline
\end{tabular}

Note: The country clusters include: 1) CAN, FRA, GBR, IRL and USA; 2) DNK, FIN, NOR and SWE; 3) AUT, BEL, CZE, DEU, EST, NLD and POL; 4) ITA and SVK; 5) JPN and KOR with cluster 1) being the reference group omitted from the regression. The industry clusters include: 1) agriculture, forestry and fishing (A) and mining and quarrying (B); 2) manufacturing (C); 3) utilities (D \& E) and construction (F); 4) information and communication $(\mathrm{J})$ and financial and insurance activities $(\mathrm{K}) ; 5)$ public services (O \& P \& Q) and 6) other business, social and personal services ( $\&$ \& H \& I \& L \& M \& N \& R \& S) with 1) being the reference group. When individual FE are employed, AUS and agriculture are the reference groups. Robust standard errors are clustered at the country level. *,**, and *** indicate that coefficients are significant at the $10 \%, 5 \%$ and $1 \%$ levels, respectively.

Source: Author's own compilation. 